\title{
Anglo-Saxon and related entries in the Oxford Dictionary of National Biography (2004)
}

HELEN FOXHALL FORBES, MATTHIAS AMMON, ELIZABETH BOYLE, CONAN T. DOYLE, PETER D. EVAN, ROSA MARIA FERA, PAUL GAZZOLI, HELEN IMHOFF, ANNA MATHESON, SOPHIE RIXON AND LEVI ROACH

The Oxford Dictionary of National Biography $(O D N B)$, originally designated the New Dictionary of National Biography, was published in 2004 as a successor to the renowned Dictionary of National Biography $(D N B)$, edited by Sir Leslie Stephen (1832-1904) and itself published in sixty-three volumes between 1885 and 1900 , with supplements. All of the subjects in the old $D N B$ were retained for the $O D N B$; new entries were commissioned for a significant proportion of the existing subjects (including almost all of those falling within the early medieval period); and of course the opportunity was taken to add entries for a large number of new subjects. In its print version, the $O D N B$ occupies sixty volumes, though it is unlikely to be found in that form outside reference libraries; most importantly, it is also available online, to subscribing institutions, with search facilities and other useful features. Like its most distinguished predecessor, the $O D N B$ is already well established as an invaluable academic resource.

It is not the purpose of this article to reflect on the criteria for inclusion, or on the mode of treatment, or to discuss how respects in which the old $D N B$ had come to show its own age had necessitated the production of a modern successor blazing a new historiographical path for the twenty-first century. More mundanely, it is to register the existence of the quantity and range of entries in the $O D N B$ on 'Anglo-Saxon' and 'related' subjects, and in this way to advertise its credentials as a massive collaborative achievement of a certain and indispensable kind. The $O D N B$ includes re-assessments of familiar subjects, including Arthur (O. J. Padel), the Sutton Hoo burial (J. Campbell), Cuthbert (D. Rollason and B. Dobson), Aldhelm (M. Lapidge), Bede (J. Campbell), Alcuin (D. Bullough), Alfred the Great (P. Wormald), Ælfric (M. Godden) and Edward the Confessor (F. Barlow), alongside accounts of many other or lesser figures. It also provides excellent coverage of 'Welsh', 'Scottish' and 'Irish' subjects, across the same period. No less important for the AngloSaxonist are the entries on twelfth- and thirteenth-century historians, such as William of Malmesbury (R. M. Thomson) and Matthew Paris (S. Lloyd and R. Reader), and the entries on a wide range of antiquaries and scholars, from John 


\section{Helen Foxball Forbes et al.}

Leland (J. Carley) and Sir Robert Cotton (S. Handley) to Elizabeth Elstob (M. Gretsch), John Mitchell Kemble (J. D. Haigh) and Sir Frank Stenton (J. C. Holt).

In the 'Bibliography for 2004', published in Anglo-Saxon England 34 (2005), all of the contributions were subsumed under a single entry:

Matthew, H. C. G., and Brian Harrison, ed., Oxford Dictionary of National Biography, in association with the British Academy: from the Earliest Times to the Year 2000, 60 vols. with index of contributors as suppl. vol. (Oxford)

This entry does not begin to do justice to the work of all those who contributed 'Anglo-Saxon' and related entries to the $O D N B$. It was felt, however, that the inclusion of separate entries in the annual bibliography, for each contributor, distributed between the relevant sections, would overload the rest of the bibliography and detract from its usefulness. At the same time, it would not accord with the nature of the $O D N B$ to isolate the 'Anglo-Saxon' entries from those covering other parts of Britain and Ireland; and it was felt that a separate listing of all of the $O D N B$ entries for the period might be of some interest and value in its own right. Users of the $O D N B$ who have access only to the online version may also find it helpful for one reason or another to have the bibliographical details of a particular contribution in the printed work.

The great majority of the entries registered below are of a standard biographical type, written in accordance with the principles laid down by the general editors of the $O D N B$. In addition to these entries, there are several 'joint entries', in which one or two additional family members are appended to the main entry, and several 'group-entries', bringing together a number of subjects who for whatever reason did not rate separate treatment in their own right but who could be usefully covered as part of a larger group. ${ }^{1}$

In its online form, the $O D N B$ is able to publish additional entries at frequent intervals. An entry for Patrick Wormald (A. May) was published in January 2008. The $O D N B$ is also supplemented regularly, in its online form, by 'Themes' of three types. The 'Reference lists' comprise organized sets of links to a selection of separate entries, with some explanatory text. Among the subjects currently available are the following: 'Rulers of Anglo-Saxon kingdoms (5th cent.-924)', 'Archbishops of Canterbury', 'Archbishops of York', 'Consorts of the monarchs

1 Anglo-Saxon group-entries: kings of the East Saxons (B. Yorke), of the people of Kent (B. Yorke), of the South Saxons (S. E. Kelly), and of the Hwicce (P. Sims-Williams). 'British' group-entry: Roman officials (A. R. Birley). 'Scottish' group-entries: abbots of Iona (T. M. Charles-Edwards); kings of Dál Riata (M. O. Anderson) and of the Picts (M. O. Anderson). 'Irish' group-entries: saints of Connacht (T. M. Charles-Edwards), saints of Leinster (C. Doherty), saints of Meath (N. Stalmans and T. M. Charles-Edwards), saints of Munster (E. Johnston) and saints of Ulster (T. M. Charles-Edwards). 


\section{Anglo-Saxon and related entries in the ODNB (2004)}

of England', 'High-Kings of Ireland', 'Monarchs of England', 'Monarchs of Scotland', 'Saints in the Oxford DNB' and 'Viking and Scandinavian kings and leaders in the Oxford $D N B$ '; new entries on individual subjects are listed, under 'Reference lists', as 'Updates'. The 'Reference groups' are substantive entries in their own right, bringing together significant groups of subjects, some but not all of whom may be treated separately in the main dictionary; examples currently available include 'Gregorian mission (act. 596-601)' (N. P. Brooks), 'Scholars at King Alfred's Court (act. 880-899)' (M. Lapidge), 'Cynfeirdd (act. 6th-11th cent.)' (M. E. Haycock) and 'Companions of the Conqueror (act. 1066-71) (C. P. Lewis). The 'Feature essays' are more wide-ranging; examples currently available include 'Roman Britain' (P. Salway), 'The rising of Owain Glyn Dwr' (Ll. Smith), 'The Isle of Man' (B. Maddrell) and 'School founders and patrons in England, 597-1560' (N. Orme).

The various forms of entry in the $O D N B$ are covered in the listing below under various numbered sections. In section 1 , the names of those who contributed new entries to the $O D N B$ are arranged in alphabetical order, with an indication of the subjects in question. In these sections, the subjects themselves are reduced to their bare names, without titles or dates, in order to avoid large-scale duplication; fuller details, derived from the $O D N B$ entries, are given in the later sections. Joint-entries and group-entries are treated under the contributor's name as single entries; the subjects mentioned within such entries are registered separately in the later sections, although in some cases it will be found that there is little more than a passing reference. The names of these who revised existing entries, whether derived from the old $D N B$ or (for example) from the Missing Persons supplement (1993), are given where appropriate below. Sections $2-6$ cover subjects in the $O D N B$ who fall within the chronological limits which had to be set for the present purpose (400-1100). In October 2006, a search for all subjects in the $O D N B$ database who flourished within this period generated a data-set of 1,290 names, which could be arranged in alphabetical order, in birth-date order, or in death-date order. Within this data-set one could search for men (1196), or for women (94). One could also generate a list of all those believed to have been alive in any specified year (24 alive in 400; 84 alive in 500; 160 alive in 600; 144 alive in 700; 93 alive in 800; 70 alive in 900; 120 alive in 1000; 351 alive in 1100); or a list of all those associated with specified places (e.g. Cambridge, 2; London, 40; Oxford, 10; Winchester, 54; York, 46); or (overlapping) lists of those with particular fields of activity (e.g. 'Royalty, rulers and aristocracy', 607; 'Religion and belief, 596; 'Scholarship and research', 78). The subjects were divided into four main groups. The largest is inevitably a set of 'Anglo-Saxon' entries, which includes persons of Scandinavian, Norman and other extraction who are known to have come to England before 1066 (section 2); there are also groups labelled 


\section{Helen Foxhall Forbes et al.}

'British', 'Welsh', 'Irish' and 'Scottish', which in view of many complications have to be taken in much the same spirit (sections 3-6). Within each of these sections, subjects are classified for the user's convenience under generic subheadings, whether 'Kings and rulers', 'Ecclesiastics' or 'Secular men and women'; again, the many anomalies are easily detected.

Sections 7-9 are necessarily of a different nature. Section 7 includes a selection of subjects who flourished between $c .1080$ and c. 1450, whose writings bear directly or indirectly on our perception of the early medieval past, starting with those who wrote about Anglo-Saxon saints (Goscelin, Folcard, et al.), the AngloNorman historians (Florence of Worcester, Eadmer, William of Malmesbury, et al.), and the main thirteenth-century historians (Roger of Wendover, Matthew Paris, et al.). These subjects are listed in alphabetical of their first name. Section 8 covers a selection of 'Antiquaries' who flourished between c. 1450 and c. 1750, who in their different ways laid the foundations for current understanding of the period, including Leland, Parker, Cotton, Dugdale, Wanley, and many others. Section 9 covers a selection of 'Modern scholars' who were active between $c$. 1750 and c. 2000, including Astle, Kemble, Stenton and Whitelock. The subjects in sections 8-9 are listed in alphabetical order of their surname.

Throughout these lists, an asterisk $\left(^{*}\right)$ signifies a woman; that there are so few is of course instructive.

Entries for a majority of the subjects in the $O D N B$ will be found in the old $D N B$, and in many cases the old entries are of interest as an indication of the perception of the given subject at the end of the nineteenth century. A valuable feature of the $O D N B$, in its online form, is that all of the 'original' entries in the old $D N B$ can be seen simply by clicking on ' $D N B$ Archive' in the left-hand column of the new or revised entry. In the classified lists below, the name of the $D N B$ contributor is given, after the reference. It so happens that over 200 of the 'Anglo-Saxon' entries were written by William Hunt (1842-1931), here identified by his initials WH. An entry for him is to be found in the ODNB. Some of his entries (for example, those on Ælfric and Wulfstan) show how far scholarship has moved forwards since his day, but overall he deserves credit as one who made a sustained effort to work things out from first principles. Other recurrent contributors are similarly identified here only by their initials: Mary Bateson (MB); Alice M. Cooke (AMC); C. L. Kingsford (CLK); J. E. Lloyd (JEL); A. J. G. Mackay (AJGM); Norman Moore (NM); Thomas Olden (TO); A. F. Pollard (AFP); W. R. W. Stephens (WRWS); D. L. Thomas (DLT); E. M. Thompson (EMT); and T. F. Tout (TFT).

The work involved in the compilation of this article was undertaken by the group of graduate students named at the top of the first page, based in the Department of Anglo-Saxon, Norse, and Celtic, University of Cambridge. The task was organized by Helen Foxhall Forbes, as co-ordinating editor; and 


\section{Anglo-Saxon and related entries in the ODNB (2004)}

Elizabeth Boyle helped in the editing of the 'Celtic' elements. Simon Keynes and Rosalind Love acted as general editors, with guidance from their colleagues Fiona Edmonds, Jonathan Grove, Máire Ní Mhaonaigh and Paul Russell.

Simon Keynes

\section{Summary}

1. CONTRIBUtORS AND THEIR SUBJECTS 187

2. 'ANGLO-SAXON' AND 'NORMAN' SUBJECTs (c. 400-c. 1100) 196

Kings, consorts and other rulers, 196; Ecclesisastics, 202; Secular men and women, 208

3. 'BRitish' SUBjECTS (c. 400-c. 600) 210

Kings, consorts and other rulers, 210; Ecclesisastics, 210; Secular men and women, 211

4. 'WELSH' SUBJECTS (c. 600-c. 1100)

Kings, consorts and other rulers, 212; Ecclesisastics, 213; Secular men and women, 214

5. 'IRISH' SUBJECTS (c. 400-c. 1100)

Kings, consorts and other rulers, 214; Ecclesisastics, 216; Secular men and women, 221

6. 'SCOTTISH' sUBJECTS (c. 400-c. 1100)

Kings, consorts and other rulers, 221; Ecclesisastics, 223; Secular men and women, 224

7. LATER MEDIEVAL SUBJECTS (c. 1080-c. 1450)

8. ANTIQUARIES (c. 1450-c. 1750)

9. MODERN SCHOLARS (c. 1750-)

\section{CONTRIBUTORS AND THEIR SUBJECTS}

Abbott, D. M.: George Buchanan, viii.468-72

Abels, Richard: Byrhtnoth, ix.333-5; Thorkell the Tall, liv.586-7; Ulfcytel, lv.865

Abrams, L.: Ailnoth, i.490-1; Rodulf, xlvii.506; Sigfrid, 1.594

Aird, William M.: Copsi, xiii.377; Robert Cumin, xiv.623; Gospatric, xxii.1033-4; Morcar, xxxix.10-11; Osulf, xlii.72; Siward, 1.812-13; Tostig, lv.67-9; Uhtred, lv.863-4

Aitken, A. J. rev:: Sir William Alexander Craigie, xiii.967-9

Alsop, J. D.: William Lambarde, xxxii.287-90

Anderson, Marjorie O.: Aedán mac Gabrán, i.378; Brude mac Bile, viii.342-3; Brude mac Maelchon, viii.343; Dál Riata, kings of, xiv.971-5; Domnall Brecc, xvi.489; Kenneth I, with Donald I, xxxi.278-9; Nechtan mac Derile, xl.313; Oengus mac Forgusso, xli.540; Picts, kings of the, xliv.243-6

Backhouse, Janet: Aldred, i.628

Barlow, Frank: Edward the Confessor, xvii.785-92; Folcard, xix.204-5; Edward Augustus Freeman, xix.920-4; Goscelin, xxii.1020-1; Gui, xxiv.182-3; Leofric, xxxiii.397; Lyfing, xxxiv.858

Barrow, G. W. S.: Malcolm III, xxxvi.279-81; Margaret, xxxvi.632-3 


\section{Helen Foxhall Forbes et al.}

Barrow, Julia: Giso, xxii.358-9; Hermann, xxvi.787-8; Oscytel, xlii.41-2; Walter, lvii.156; William, lix.32-3; Wulfsige, lx.555-6; Wulfwig, lx.566-7

Bartlett, Robert: Bega, iv.834; Gerald of Wales, xx.925-8; Jocelin of Furness, xxi.190-1; Moninne, xxxviii.625; Turgot, lv.577-8

Bates, David: William I, lix.45-57

Bell, David N.: Ailred of Rievaulx, i.491-3

Bendall, Sarah: John Speed, li.771-3

Benedikz, B. S.: Eiríkur Magnússon, xxxvi.137-9

Bibire, Paul: Arnórr Earls’ Poet, ii.511

Biddle, Martin: Rupert Lee Scott Bruce-Mitford, xxxviii.459-60

Birley, A. R.: Roman officials, xlvii.652-6

Blair, John: Botwulf, vi.773; Frithuswith, xx.50-1; Mannig, xxxvi.483-4; Mildburg, xxxviii.111-12; Osgyth, xlii.45-6; Seaxwulf, xlix.617; Spearhafoc, li.761-2; John Allen Giles, xxii.229-30

Bonner, Gerald: Pelagius, xliii.455-7

Borrie, Michael: Sir Edward Augustus Bond, vi.509-11; Francis Wormald, lx.331-2; Sir Edward Maunde Thompson, liv.420-1

Boyer, Allen D.: Sir Edward Coke, xii.451-63

Bracken, Damian: Feidlimid mac Crimthainn, xix.235-6; Mac Briain, Donnchad, xxxv.65-7; Muirchertach Ua Briain, lv.830-2; Toirdelbach Ua Briain, lv.832-3

Bremmer, Rolf H. jun.: Johannes Laet, xxxii.207

Brett, Caroline: Paul, xliii.126-7; Petroc, xliii.927; Piran, xliv.402-3

Brooks, N. P.: Laurence, xxxii.691; Mellitus, xxxvii.751-2; Oswald, xlii.79-84; Wulfred, 1x.552-4; see also 'Gregorian mission (act. 596-601)', Reference group (online)

Broun, Dauvit: Constantine I, xiii.32; Constantine II, with Donald II, xiii.32-3; Culen, with Constantine III, xiv.572-3; Dubh, with Macduff, xvii.11-12; Duncan I, xvii.218-19; Giric mac Dúngal, xxii.347; Indulf, xxix.230; Kenneth II, xxxi.279-80; Kenneth III, xxxi.280; Kentigern, xxxi.333-4; Macbeth, with Lulach, xxxv.59-60; Malcolm I, xxxvi.278-9; Malcolm II, xxxvi.279; Mawgan, xxxvii.479-80; Ninian, xl.919

Bullough, D. A.: Alcuin, i.602-8

Cameron, M. L.: Bald, iii.436

Campbell, James: Bede, iv.758-65; Rædwald, xlv.786; Sigeberht, 1.592; Stubbs, William, liii.217-22; Sutton Hoo burial, liii.416-17

Carey, John: Cináed ua hArtacáin, xi.713; Cuán ua Lothcháin, xiv.574-5; Eochaid ua Flannucáin, xviii.472-3; Flann Mainistrech, xix.997-8; Máel Muru Othna, xxxvi.100-1

Carley, James P.: Leland, John, xxxiii.297-301; Robert Talbot, liii.722-3

Charles-Edwards, T. M.: Áed Allán mac Fergaile, i.373; Áed Oirdnide mac Néil, i.374 5; Áed Uaridnach mac Domnaill, i.376; Blaímac mac Áeda, vi.70; Brigit, with Conlaíd and Dar Lugdach, vii.650-4; Brochfael Ysgithrog, vii.742-3; Brynach, viii.429-30; Cadfan, ix.408; Cadog, ix.410-12; Cadwallon ap Cadfan, ix.425-6; Cellach mac Máele Coba, with Conall Cóel mac Máele Coba, x.805-6; Cenn 


\section{Anglo-Saxon and related entries in the ODNB (2004)}

Fáelad mac Blaímaic, x.810; Cináed mac Írgalaig, xi.712-13; Congal Cáech, xii.929; Connacht, saints of, xii.960-3; Cybi, xiv.857; Cyfeilliog, xiv.857-8; Cynidr, xiv.866-7; Dallán Forgaill, xiv.954-5; Deiniol, xv.696; Dergain, xxii.963; Diarmait mac Cerbaill, xvi.22-3; Dogfael, xvi.451; Domnall mac Áeda, xvi.489_ 90; Domnall mac Murchada, xvi.490; Dubthach maccu Lugair, xvii.22-3; Elfoddw, xviii.31; Fínsnechtae Fledach mac Dúnchada, xix.629; Flaithbertach mac Loingsig, xix.979; Forggus mac Muirchertaig, xix.366-7; Gwallawg, xxiv.336; Gwenfrewi, xxiv.340-1; Gwynllyw, xxiv.360-1; Iarlaithe, xxix.179-80; Iona, abbots of, xxix.316-21; Máel Sechnaill mac Máele Ruanaid, xxxvi.102-4; Meath, saints of, see Stalmans, Nathalie; Muirchertach mac Muiredaig, xxxix.681-2; Mynyddog Mwynfawr, xl.87; Niall mac Maíl Shechnaill, xl.746-7; Palladius, xlii.461-2; Suibne Menn mac Fiachnai, liii.290; Taliesin, liii.737-8; Tigernach Ua Braín, lv.889; Tuathal Máelgarb mac Cormaic, lv.484-5; Ulster, saints of, lv.8728; Vorteporius, lvi.594-5

Chibnall, Marjorie: Geoffrey, xx.762-3; William of Poitiers, xliv.682-3

Christianson, Paul: John Selden, xlix.694-705

Clapinson, Mary: Richard Rawlinson, xlvi.162-4

Clunies Ross, Margaret \& Amanda J. Collins: Edward Thwaites, liv.732-3

Coates, S. J.: Benedict Biscop, v.64-6; Ceolfrith, x.817-19

Contreni, John J.: Dícuil, xvi.132-4; Martin of Laon, xxxvi.917-18

Cooper, Janet: Cynesige, xiv.861

Corner, David: Roger of Howden, xxviii.463-4; Roger of Wendover, lviii.106-8

Costambeys, Marios: Adalbert, i.190; Æthelburh, i.401; Æthelflæd, i.401-3; Æthelred, i.407-8; Albinus, i.587-8; Beornred, v.316; Burchard, viii.725-6; Colmán, xii.7567; Cyngar, xiv.864-5; Disibod, xvi.264; Donnán, xvi.531-2; Ealhswith, xvii.5556; Erhard, xviii.496-7; Erik Bloodaxe, xviii.497-9; Felix, xix.253; Fredericus, xix.914-15; Guthrum, xxiv.322; Hálfdan [Healfdene], xxiv.562-3; Ívarr [Ívarr inn Beinlausi], xxix.443-5; Jænberht, xxix.580; Lebuin, xxxiii.22-3; Lul, xxxiv.740-1; Nigel, xl.900; Odhran, xli.496; Paulinus, xliii.166-8; Ragnall Guthfrithson, xlv.796-7; Sihtric inn Gamli, 1.597; Sihtric inn Ungi, 1.597; Sualo, liii.261; Swithberht, liii.523; Waldhere, lvi.781-2; Willehad, lix.16; Willibrord, lix.363-8

Couper, Sarah: John Pinkerton, xliv.373-5

Cowdrey, H. E. J.: Robert of Jumièges, xlvii.122-3; Stigand, lii.774-7

Cownie, Emma: Robert de Brus, viii.372

Cox, D. C.: Dominic of Evesham, xviii. 802

Craig, D. J.: Adda, xxix.189; Ida, xxix.188-9; Osric, xlii.61-2; Osric, xlii.62; Oswald, xlii.76-9; Oswine, xlii.93-4; Oswiu, xlii.94-7

Cramer, P.: Ernulf, xviii.511-12

Cramp, Rosemary: Ælla, i.391-2; Æthelfrith, i.403-4; Alchfrith, i.589; Aldfrith, i.61819; Eadwine, xvii.543-6

Crankshaw, David J., \& Alexandra Gillespie: Matthew Parker, xlii.707-28

Crawford, Barbara E.: Einarr, xvii.1023-4; Hákon Paulsson, xxxvi.130-1; Paul, with Erlend, xliii.128-9; Sigurd (II) Hlödvisson, 1.595-6; Thorfinn Sigurdson, with Rögnvald (II) Brúsason, liv.584-5 


\section{Helen Foxhall Forbes et al.}

Crick, J. C.: Geoffrey of Monmouth, xxxviii.629-32

Cubitt, Catherine, \& Marios Costambeys: Oda, xli.484-7

Dalton, Paul: Norman Darcy (I), xv.130

Damian-Grint, Peter: Haimo [Haymo], xxiv.479

Davies, Luned Mair: Cú Chuimne, xiv.574; Modestus, xxxviii.486; Sedulius Scottus, xlix.660-1; Ruben mac Connad, xlviii.66

Dearden, James S.: William Gershom Collingwood, xii.681-3

Dockray-Miller, Mary: Mary Bateson, iv.331-3

Doggett, Nicholas: Thomas Gale, xx.303-5

Doherty, Charles: Cellach Cualann, x.804-5; Congal Cendmagair, xii.929-30; Donnchad Donn mac Flainn, xvi.532-3; Donnchad mac Domnaill, xvi.533-4; Fergal mac Máele Dúin, xix.338-9; Flann Sinna, xix.998-9; Leinster, saints of, xxxiii.277-9; Ruaidrí ua Canannáin, xlviii.62-3

Duffy, Seán: Áed Ua Conchobair, lv.835-6; Brian Bóruma, vii.533-8; Cathal mac Conchobair, x.536; Conn na mBocht, xii.957-8; Flaithbertach Ua Néill, lv.844-5; Godred Crovan, xxii.600-1; Ruaidrí Ua Conchobair, lv.836

Dunning, Robert W., William Hunt, xxviii.877-8

Du Toit, Alexander: George Chalmers, xi.870-2; Thomas Dempster, xv.759-62

Edwards, Francis: Joseph Stevenson, lii.588-90

Edwards, Heather: Æthelheard, i.404-5; Beorhtric, v.314-15; Cuthred, xiv.837-8; Cynewulf, xiv.863-4; Ecgberht, xvii.636-9; Sigeberht, 1.592-3

Evans, J. Wyn: David, xv.277-82; Non, xv.279

Evans, Mihail Dafydd: John Davies, xv.381-2; Robert Powell Vaughan, lvi.198-9

Farmer, D. H.: Baldred, iii.617-18; Balthere, iii.617-18; Ceadda, x.713-14; Cedd, x.800-1; Robert of Shrewsbury, 1.454

Flanagan, M. T.: Donngus Ua hAingliu, lv.842-3

Fleming, Robin: Harold II [Harold Godwineson], xxv.356-62

Foot, Sarah: Æthelstan, i.420-8

Foote, Yolanda: John Obadiah Westwood, lviii.318-19

Ford, Alan: James Ussher, lvi.6-14

Fouracre, Paul: Agilbert, i.457-8; Foillan, xix.203-4; Fursa, xx.201-2; Leuthere, xxxiii. 516

Fox, Adam: John Aubrey, ii.907-11

Franklin, M. J.: Walkelin, lvi.805-6

Gameson, Richard: Aelsinus (Ælfsige), i.393; Eadwig Basan, xvii.542-3

Ganz, David: Bernard, v.417; Dúngal, xvii.297-8

Garrison, Mary: Fridugisus, xx.27-8; Hygbald, xxix.158-9; Joseph Scottus, xxx.715-16

Geraint Gruffydd, R.: Sir Idris Llewelyn Foster, xix.504-5

Gillies, William: Kenneth Hurlstone Jackson, xxix.509-10

Godden, Malcolm: Ælfric of Eynsham, with Ælfric Bata, i.387-8

Gransden, Antonia: Edmund, xvii.754-5; Hermann, xxvi.787-8

Gray, Douglas: Guy of Warwick, xxiv.328-9

Greatrex, Joan: Henry Bradshaw, vii.213

Green, Judith A.: Baldwin, iii.441 


\section{Anglo-Saxon and related entries in the ODNB (2004)}

Greenway, D. E.: Henry [Henry of Huntingdon], xxvi.413

Gretsch, Mechthild: Elizabeth Elstob, xviii.335-7

Gruffydd, R. Geraint: William Morgan, xxxix.152-5

Haigh, John D.: John Mitchell Kemble, xxxi.153-4

Hall, A. T.: William Douglas Simpson, 1.718-9

Hall, Ursula: Regulus, xlvi.373-4

Halloran, Brian M.: Thomas Innes, xxix.307-8

Hamilton, Alistair: Abraham Wheelocke, lviii.444-7

Handley, Stuart: Sir Robert Bruce Cotton, xiii.624-9; Sir Henry Spelman, li.791-3

Harmsen, Theodor: Thomas Hearne, xxvi.156-60; George Hickes, xxvii.5-11

Harries, Jill: Germanus, xx.965-6

Harris, Jennifer: Joseph Strutt, liii.120-1

Hart, Cyril: Æthelstan, i.428-9; Æthelwine, i.433-4; Edward, xvii.783-5; Guthfrith, 1.597; Oslac, xlii.51; Ragnall, xlv.796; Sihtric Cáech, 1.597; Wulfstan, lx.557-8

Harvey, Barbara F.: Sulcard, liii.292

Haycock, David Boyd: William Stukeley, liii.231-5

Haycock, M. E.: Merlin, xxxvii.898-9; see also 'Cynfeirdd (act. 6th-11th cent.)', Reference group (online)

Herbert, Máire: Columba, xii.805-10

Herendeen, Wyman H.: William Camden, ix.603-14

Hewitt, David: Sir Walter Scott, xlix.490-510

Heyworth, Peter: Humfrey Wanley, lvii.239-42

Holt, J. C.: Sir Frank Merry Stenton, lii.405-7

Hooper, Nicholas: Christina, xi.584

Horden, Peregrine: Faricius, xix.43-4

Hudson, Benjamin T.: Áed mac Néill, i.373-4; Cellachán mac Buadacháin, x.806; Cerball mac Dúngaile, x.821-2; Conchobar mac Donnchada (online update, Oct. 2005); Congalach mac Máele Mithig, xii.930; Diarmait mac Máel na mBó, xvi.23; Domnall ua Néill, xvi.490-1; Dub dá Leithe, xvii.9-10; Dúnán, xvii.199-200; Ealdred, xvii.551-2; Lethlobar mac Loingsig, xxxiii.509-10; Máel Sechnaill mac Domnaill, xxxvi.101-2; Muirchertach mac Néill, xxxix.682-3; Niall mac Áeda, xl.744-5; Niall mac Áeda, xl.745; Niall mac Eochada, xl.746; Óláf Guthfrithson, xli.662-3; Óláf Sihtricson, with Sihtric Cam, xli.663-5; Óláf the White, xli.665; Sihtric, 1.596-7; Turges, lv.576

Hüllen, Werner: Vivien Anne Law, Lady Shackleton (online update, October 2006)

Huws, Daniel: Thomas Jones, xxx.635-6

Irwin, Philip: Áed Sláine mac Diarmata, i.375-6; Ailill Molt, i.490; Báetán mac Cairill, iii.212; Cathal mac Finguine, x.536-7; Coirpre mac Néill, xii.441; Fiachu mac Néill, xix.462; Fogartach mac Néill, xix.199-200; Lóegaire mac Néill, xxxiv.2923; Lugaid mac Lóegairi, xxxiv.724; Nath Í mac Fiachrach, xl.264; Niall Frossach mac Fergaile, xl.743-4; Sechnassach mac Blathmaic, xlix.621

Jayatilaka, R.: Finán, xix.549-50

John, James J.: Elias Avery Lowe, xxxiv.563 


\section{Helen Foxhall Forbes et al.}

Johnston, Elva: Beoán, v.314; Fiachra, xix.461-2; Gormlaith, xxii.1011; Mo Ling, with Gobbán Sáer, xxxviii.469-70; Mo Nennus, xxxviii.470-1; Munster, saints of (c. 450-c. 700), xxxix.783-93; Nathalan, xl.264-5; Senchán Torpéist, xlix.753-4; Urard mac Coise, lv.936

Jones, Nerys Ann: Pabo, xlii.295-6; Padarn, xlii.315

Jones, R. Brinley: Humphrey Llwyd, xxxiv.174-6; William Salesbury, xlviii.696-9

Kellett, Arnold: Joseph Wright, lx.464-7

Kelly, Fergus: Eugene O’Curry, xli.483-4; Níall Noígíallach, xl.747-8

Kelly, S. E.: Ælle, i.392; Æthelbald, i.393-5; Æthelberht I, i.398-400; Æthelberht II, joint king of Kent, with others (8th cent.), i.400-1; Anna, ii.169; Baldred, iii.440; Beornwulf, v.316-17; Berhtwulf, v.348-9; Burgred, viii.815-16; Ceolred, x.819-20; Coenred, xii.393; Cwenthryth, xiv.856-7; Cynethryth, xiv.861-2; Eadbald, xvii.5212; Eadberht Præn, xvii.523; Thomas Elmham, xviii.294; Eorcenberht, with Ecgberht I, xviii.473; Hlothhere, with Eadric, xxvii.339-40; Offa, with Ecgfrith, xli.545-8; Osthryth, xlii.65; Peada, xliii.263; Penda, xliii.515-16; South Saxons, kings of, li.702-3; Wiglaf, lviii.853-4; Wihtred, lviii.864; Wulfhere, lx.550-1

Kenneally, Daniel F.: Thomas Oswald Cockayne, xii.326-7

Kerlouégan, François: Gildas, xxii.223-5

Keynes, Simon: Æthelred II, i.409-19; Æthelstan ætheling, i.429; Eadric Streona, xvii.535-

8; Eadwig, xvii.539-42; Emma, xviii.412-14; Dorothy Whitelock, lviii.692-4

King, Edmund: Eustace, xviii.648-9; Hugh Candidus, xxviii.620-1; Ingulf, xxix.294-5

King, John N.: John Bale, iii.482-6

Knobel, Paul: Nora Chadwick, x.847-8.

Krag, Claus: Harald Hardrada, xxv.100-1

Lapidge, Michael: Aldhelm, i.619-23; Byrhtferth of Ramsey, ix.332-3; Cellán, x.806-7;

Dunstan, xvii.347-53; Ecgwine, xvii.640-1; Frithegod, xx.49; Hadrian, xxiv.437-

8; Hildelith, xxvii.91-2; John the Old Saxon, xxx.204; Lantfred, xxxii.545-6;

Máeldub, xxxvi.99-100; Neot, xl.424; Oswald, xlii.84; Rhigyfarch ap Sulien, xlvi.589-90; Tatwine, liii.831-2; Theodore of Tarsus, liv.226-30; Wulfstan Cantor, 1x.564-5; see also 'Scholars at King Alfred's court (act. 880-899)', Reference group (online)

Larrington, Carolyne: Hugeburc, xxviii.599-600; Walburg, lvi.758; Willibald, lix.363; Winnebald, lix.746

Law, V. A.: Clemens Scotus, xii.17-18

Lawson, M. K.: Alfred Ætheling, i.727; Cenwulf, x.817; Cnut, xii.239-46; Edmund II, xvii.769-70; Edward Ætheling, xvii.896-7; Harold I [called Harold Harefoot], xxv.355-6; Harthacnut, xxv.602-3

Levy, F. J.: Henry Savile, of Banke, xlix.118

Lewis, C. P.: Gundrada de Warenne, lvii.392; Ordgar, xli.923; Ordgar, xli.922-23; Ordgar, xli.923; Osbern fitz Richard, xlvi.757; Richard Scrob, xlvi.756-7; Thurcytel, liv.709; Waltheof, lvii.187-9; Withman, lix.890; see also 'Companions of the Conqueror (act. 1066-71), Reference group (online)

Leyser, Henrietta: Ælfheah, i.382-3; Eve of Wilton, lix.667; Kentigerna, xxxi.334; Wulfhelm, lx.550 


\section{Anglo-Saxon and related entries in the ODNB (2004)}

Leyser, Karl: (John) Michael Wallace-Hadrill, xxiv.438-9

Lloyd, Simon, \& Rebecca Reader: Matthew Paris, with John of Wallingford, xlii.620-8

Loyn, H. R.: Sharon Turner, lv.661-3

Lucas, Peter J.: John Capgrave, ix.991-3

Lund, Niels: Ohthere, xli.639; Óláf Tryggvason, xli.665-6

MacCarthy, Fiona: William Morris, xxxix.317-24

Macfarlane, Leslie J.: William Elphinstone, xviii.326-8

MacMahon, M. K. C.: Arthur Sampson Napier (online update, October 2007); Henry Sweet, liii.447-50

Macquarrie, Alan: Catroe, x.559-60; Donald, xvi.494; Monan, xxxviii.574-5; Owen the Bald, xvi.494; Ternan, liv.153-4

Maddicott, J. R.: Ecgfrith, xvii.639-40

Marenbon, John: Candidus, ix.888-9; John Scottus [John Scottus Eriugena], xxx.196-203

Martin, G. H.: John Joscelin, xxx.714-15; John Smith, li.205-6; William Henry Stevenson, lii.612-13

Mason, Emma: Ælfric, i.385; Ælfwine, i.391; Æthelnoth, i.406-7; Æthelric, i.419-20; Athelm, ii.806; Lyfing, xxxiv.857-8; Sigeric, 1.593; Wulfstan, lx.562-4

Mason, J. F. A.: Hemming, xxvi.280

Maund, K. L.: Ealdgyth, xvii.551; Herewald, xxvi.766-7

May, Alex: Patrick Wormald (online update, January 2008)

Mayr-Harting, Henry: Áedán, i.376-7; Augustine, ii.948-50; Ecgberht, xvii.635-6; Guthlac, xxiv.301-2

McGurk, P.: Florence of Worcester, 1x.292; John of Worcester, 1x.292-3

Meehan, Bernard: Symeon of Durham, liii.581-2

Meens, Rob, Columbanus, xii.810-13

Miller, Sean: Æthelbald, i.395-6; Æthelberht, i.397-8; Æthelred I, i.408-9; Ceolwulf II, x.821; Ecgberht, church reformer, xvii.634-5; Edward, xvii.779-83

Milsom, S. F. C.: Frederic William Maitland, xxxvi.204-10

Mortimer, Ian: Thomas Talbot, liii. 725

Mortimer, Richard: Richard de Clare, xi.759-60

Nelson, Janet L.: Æthelwulf, with Judith, i.438-41; Balthild, iii.618-19; Bertha, v.479_ 80; Eadburh, xvii.524; Eadgifu, xvii.526-7; Hæsten, xxiv.440-1; Osburh, xlii.40

Ní Dhonnchadha, Máirín: Adomnán, i.353-6; Loingsech mac Óenguso, xxxiv.329

Ó Briain, Mairtin: Oisín, xli.645

O'Donoghue, Bernard: Robin Ernest William Flower, xx. 177-8

O’Donoghue, Heather: Gabriel Turville-Petre, xliii.907-8

O’Loughlin, Thomas: Ailerán, i.489-90

Ó Muraíle, Nollaig: Dubhaltach Óg Mac Fhirbhisigh, xxxv.387-8; Míchél Ó Cléirigh, xli.433-5; John O’Donovan, xli.527-9; Whitley Stokes, lii.872-4

Ó Riain, Pádraig: Óengus of Tallaght, xli.540-1

Ó Riain-Raedel, Dagmar: Deicolus, xv.695; Gall, xx.307-8; Killian, xxxi.548-9; Virgilius, lvi.561-2

Orme, Nicholas: Nicholas Roscarrock, xlvii.730-1; William Worcester, 1x.294-5 


\section{Helen Foxball Forbes et al.}

Owen, Morfydd: Aneirin, ii.141-2

Padel, O. J.: Arthur, with Uther Pendragon, ii.529-43; Gudwal, with Gulval, xxiv.165-6

Palliser, D. M.: John of Beverley, xxx.193-4

Parry, Graham: Roger Dodsworth, xvi.440-1; Sir William Dugdale, xvii.153-7

Pettegree, Andrew: John Day, xv.584-6

Pfaff, Richard W.: Abbo of Fleury, i.10-11; Grimbald, xxiv.19-20; Montague Rhodes James, xxix.723-6; Ursula, lv.958-9; Werferth, lviii.166-7

Pontfarcy, Yolande de: Henry of Saltrey, xlvii.775-6

Prestwich, J. O.: Orderic Vitalis, xli.921-2

Price, Angharad: Siôn Dafydd Rhys, xlvi.626-7

Pryce, Huw: Bleddyn ap Cynfyn, with Rhiwallon ap Cynfyn, Sir Owain ap Cadwgan and Iorwerth ap Bleddyn, vi.198-9; Gruffudd ap Cynan, with Iago ab Idwal ap Meurig, xxiv.133-5; Sir John Prise, xlv.424-5

Ramsay, Nigel: Thomas Astle, ii.771-3; Bryan Faussett, xix.159-60

Reuter, Timothy: Clement, xii.18-19

Rhodes, Michael: Charles Roach Smith, li.67-9

Rigg, A. G.: Godfrey of Winchester, lix.688-9

Roberts, Brynley F.: Edward Lhuyd, xxxiii.710-12

Roberts, R. Julian: John Dee, xv.667-75

Roffe, David: Hereward [called Hereward the Wake], xxvi.767-8; Leofric, xxvi.767

Rollason, David: Ælberht, i.378-9; Ælle, i.392; Aldhun, i.623-4; Billfrith, v.720; Ceolwulf, x.820-1; Cynehelm, xiv.860-1; Eadberht, xvii.522-3; Ealhmund, xvii.554-5; Eanbald (I), xvii.556-7; Eanbald (II), xvii.557; Eardwulf, with Eanred, Æthelred II and Rædwulf, xvii.562-3; Mildrith, xxxviii.126-7; Osbald, xli.979; Osberht, xli.982-3; Osred I, xlii.60-1; Osred II, xlii.61; Oswulf, with Æthelwold Moll, Alhred, Æthelred I and Ælfwald I, xlii.97-8; Seaxburh, xlix.616; Wigstan, lviii.863; William Ketel, xxxi.447

Rollason, David, \& R. B. Dobson: Cuthbert, xiv.829-34

Romburgh, Sophie van: Franciscus Junius, xxx.834-5

Ross, Margaret Clunies, \& Amanda J. Collins: Edward Lye, xxxiv.849-51

Rowland, Jenny: Llwyarch Hen, xxxiv.180

Royan, Nicola: Hector Boece, vi.418-21

Rubenstein, J. C.: Eadmer of Canterbury, xvii.530-1; Osbern, xli.983-4

Russell, Paul: Cellach, x.803; Cormac mac Cuilennáin, xiii.434-5; Donatus, xvi.520-1

Salt, S. P.: Sir Edward Dering, xv.874-80

Sawyer, P. H.: Swein, liii.453-5; Ulf Fenisc, lv.864; Wulfric Spot, lx.555

Schoeck, R. J.: Charles Plummer, xliv.612-13; Edmund Bishop, v.864-5

Sherlock, Peter: William Somner, li.627-9

Shippey, T. A.: J. R. R. Tolkien, liv.902-5

Short, Ian: Geffrei Gaimar, xx.265-6

Sims-Williams, Patrick: Beuno, v.565-6; Burginda, viii.803; Ecgburh, xvii.639; Hwicce, kings of the, xxix.114-16; Milred, xxxviii.330; Oftfor, xli.556-7; Putta, xlv.601-2 Smith, David L.: Sir Roger Twysden, lv.750-4 


\section{Anglo-Saxon and related entries in the ODNB (2004)}

Smith, Julia M. H.: Maglorius, xxxvi.127-8; Samson, xlviii.807-8

Smith, Mary Frances: Regenbald, xlvi.364-5

Smith, Peter J.: Airbertach mac Cosse Dobráin, i.511-12; Flann mac Lonáin, xix.9967; Gilla Coémáin, xxii.253; Muirchertach, xxxix.681

Stacey, Robin Chapman: Dyfnwal Moelmud ap Garbanion, xvii.493-4

Stafford, Pauline: Ælfgifu, i.380-1; Ælfgifu, i.381-2; Ælfthryth, i.389-90; Eadgifu, xvii.527-8; Erik of Hlathir, xviii.499-500

Stalmans, Nathalie: Dympna, xvii.505-6; Forannán, xix.253-4; Plechelm, xliv.574; Rumold, xlviii.115-16

Stalmans, Nathalie, \& T. M. Charles-Edwards: Meath, saints of, xxxvii.671-8

Stancliffe, Clare: Faustus, xix.161-3; Patrick, xliii.69-80; Sedulius, xlix.659-60

Stanley, E. G.: Cædmon, ix.427-8; Cynewulf, xiv.863-4

Stephens, Meic: Gwyn Jones, xxx.504-5

Sullivan, M. G.: Paul de Rapin de Thoyras, xlvi.68-71

Summerson, Henry: Eugenius I-VIII [Scottish kings], xviii.644-5

Taylor, John: John of Tynemouth, lv.795-6; Ranulf Higden, xxvii.49-50

Taylor, Stephen: Edmund Gibson, xxii.68-75

Taylor, T. F.: Joseph Armitage Robinson, xlvii.376-8

Thacker, Alan: Acca, i.133; Æbbe, with Ebba, i.372-3; Ælffled, i.379-80; Æthelthryth, i.429-32; Boisil, vi.452; Bosa, vi.687; Brorda, vii.954-5; Deusdedit, xv.929; Eadberht, xvii.522; Eadfrith, xvii.526; Eanflæd, xvii.557-8; Eata, xvii.605-6; Hild, xxvii.90-1; Stephen of Ripon, lii.423-4; Werburh, lviii.164-5; Wilfrid, lviii.944-50

Thomson, R. M.: Eilmer, xvii.1022-3; William of Malmesbury, xxxvi.348-51

Thornton, David E.: Ambrosius Aurelianus, i.922; Asaf, ii.584-5; Barinthus, iii.857; Beulan, v.564-5; Brychan Brycheiniog, viii.412-13; Cadell ab Arthfael, ix.401; Cadell ap Rhodri, ix.401-2; Cadell Ddyrnllug, ix.402; Cadwaladr ap Cadwallon, ix.423-4; Cafan ab Iago, ix.408; Cynan Garwyn, xiv.858; Cynddylan ap Cyndrwyn, xiv.859-60; Cyngen ap Cadell, xiv.865-6; Decuman, xv.663-4; Dyfrig, xvii.494-5; Euddogwy, xviii.643; Hywel [called Hywel Fychan], xxix.171-2; Hywel ab Ieuaf, xxix.172-3; Hywel Dda, xxix.175-6; Iago ab Idwal Foel, xxix.177; Idwal ap Meurig, xxix.190; Idwal Foel, xxix.190-1; Illtud, xxix.208-9; Livinus, xxxiv.88-9; Maelgwn Gwynedd, xxxvi.100; Maredudd ab Owain, xxxvi.625-6; Merfyn Frych, xxxvii.885-6; Mordaf Hael, xxxix.11-12; Morgan ab Athrwys, xxxix.94-5; Morgan Hen, xxxix.95-6; Muirchú, xxxix.683; Nennius, xl.423-4; Owain ab Edwin, xlii.176-7; Owain ap Hywel, xlii.177; Peulan, xliii.966-7; Probus, xlv.447-8; Rhodri Mawr, xlvi.611; Rhun Hir, xlvi.611-12; Rhydderch Hen, xlvi.613; Seiriol, xlix.686; Selyf ap Cynan, xlix.737-8; Teilo, liv.28-9; Tírechán, liv.836-7; Tysilio, lv.817; Urien Rheged, lv.944; Vortigern, lvi.598-9

Todd, Andy: Æthelberht, i.396-7

Tomlin, R. S. O.: Constantine III, xiii.33-5; Gerontius, xxi.967-8

Triggs, Tony D.: Wulfstan, 1x.556-7

Tudor, V.: Reginald of Coldingham, xii.496-7

Vaisey, David: Richard William Hunt, xxvii.866-7 


\section{Helen Foxhall Forbes et al.}

van Houts, Elisabeth: Ælfthryth, i.389; Judith of Flanders, xxx.815; Matilda, xxxvii.318-20; William of Jumièges, xxx.828

Waite, Greg: Harold McCarter Taylor, liii.896-7

Walker, David: Caradog ap Gruffudd ap Rhydderch, with Gruffudd ap Rhydderch and Caradog ap Rhydderch, x.10-11; Gruffudd ap Llywelyn, xxiv.136-7; Llywelyn ap Seisyll, xxiv.136

Wareham, A. F.: Æthelred, i.407; Byrhtnoth, ix.335; Ceolnoth, x.819; Plegemund, xliv.574-5

Warnicke, Retha M.: Laurence Nowell, xli.237-9

Watt, D. E. R.: John Fordun, xx.355-7; Walter Bower, vi.921-2

Wawn, Andrew: George Stephens, lii.466-8

Williams, Ann: Ælfgar, with Eadwine, i.380; Ælfhere, with Ælfric Cild and Ælfheah, i.383-5; Ælfric, i.385-6; Ælfstan of Boscombe, i.389; Æthelheard, i.405-6; Æthelred, i.407; Asgar the Staller, ii.596-7; Beorhtric, v.315; Beorn Estrithson, v.315-16; Bregowine, vii.435; Cuthbert, xiv.834-6; Eadgifu the Fair, xvii.528; Eadnoth the Staller, xvii.531; Eadred, xvii.531-4; Eadric of Laxfield, xvii.534-5; Eadric the Wild, xvii.538-9; Edgar, xvii.698-703; Edith, xvii.738-9; Edmund I, xvii.766-9; Godgifu, xxii.574-6; Godwine, with Gytha, xxii.626-9; Gyrth, xxiv.377-8; Hygeberht, xxix.160; Leofric, xxxiii.395-7; Leofwine, xxxiii.397-8; Odda, xli.491-2; Osgod Clapa, xlii.42-3; Ralph, xlv.868-9; Ralph, xlv.869-70; Ralph the Staller, xlv.873; Robert fitz Wimarc, xlvii.121-2; Swein, liii.455-6; Tovi the Proud, lv.99-100; Wulfweard White, lx.565-6

Williams, Gruffydd Aled: Edmwnd Prys, xlv.494-5

Williams, J. E. Caerwyn: Thomas Wiliems, lviii.952-3

Wood, I. N.: Boniface, vi.540-5

Wormald, Patrick: Æthelweard, i.432-3; Alfred, i.716-25; Asser, ii.759-60; Cunedda, xiv.65; Earconwald, xvii.559-60; Ine, xxix.236-8; Wulfstan, lx.558-62

Yorke, Barbara: Ælfsige, i.388-9; Æthelwold, i.434-8; Birinus, v.831; Bugga, viii.5667; Bugga, viii.567; Byrnstan, ix.340; Cædwalla, ix.429; Ceawlin, x.715-16; Centwine, x.814-15; Cenwalh, x.815; Ceol, x.817; Ceolwulf, x.820.; Cerdic, x.822-3; Cuthburh, xiv.837; Cwichelm, xiv.857; Cynegils, xiv.860; Cynric, xiv.867; Daniel, xv.63; Denewulf, xv.770-1; Eadburh, xvii.523; Eadburh, xvii.524-5; Eadburh, xvii.523-4; East Saxons, kings of, xvii.602-4; Edith, xvii.737-8; Frithestan, xx.49-50; Hædde, xxiv.439-40; Kent, kings of, xxxi.315-16; Leoba, xxxiii.394-5; Seaxburh, xlix.616; Swithun, liii.523-5; Wihtgar, lviii.863; Wine, lix.716; Wulfhild, lx.551-2; Wulfthryth, lx.565

\section{2. 'ANGLO-SAXON' AND 'NORMAN'SUBJECTS (c. 400-c. 1100)}

\section{a. Kings, consorts and other rulers}

* Elfgifu, consort of King Eadwig (fl. 956-66): Pauline Stafford, i.380-1; DNB WH

*Ælfgifu, first consort of King Cnut (fl. 1006-36): Pauline Stafford, i.381-2; DNB WH 


\section{Anglo-Saxon and related entries in the ODNB (2004)}

*Ælfthryth, princess (d. 929): Elisabeth van Houts, i.389; $D N B$ WH

*Elfthryth, queen, consort of King Edgar (d. 999x1001): Pauline Stafford, i.389-90; $D N B$ WH

Ælfwald, king of the South Saxons (fl. c. 760): see South Saxons, kings of the Ælfwald I, king of Northumbria (d. 788): David Rollason, xlii.97-8

Ælla, king of Deira (d. in or after 597?): Rosemary Cramp, i.391-2; DNB WH Ælle, king of Northumbria (d. 867): David Rollason, i.392; DNB WH Ælle, king of the South Saxons ( $f$. late 5th cent.): S. E. Kelly, i.392; $D N B$ WH Æsc, king of Kent (d. 512?): see Kent, kings of; $D N B$ WH Æthelbald, king of the Mercians (d. 757): S. E. Kelly, i.393-5; DNB WH Æthelbald, king of the West Saxons (d. 860): Sean Miller, i.395-6; DNB WH Æthelberht, king of the West Saxons (d. 865): Sean Miller, i.397-8; DNB WH Æthelberht, king of the South Saxons (fl. 733-47?): see South Saxons, kings of the Æthelberht, king of the East Angles (779/80-94): Andy Todd, i.396-7; DNB WH Æthelberht I, king of Kent (d. 616?): S. E. Kelly, i.398-400; DNB WH Æthelberht II, joint king of Kent (d. 762), et al:: S. E. Kelly, i.400-1 *Æthelflæd, ruler of the Mercians (d. 918): Marios Costambeys, i.401-3; DNB WH Æthelfrith, king of Northumbria (d. c. 616): Rosemary Cramp, i.403-4; DNB WH Æthelheard, king of the West Saxons (d. 740): Heather Edwards, i.404-5 Æthelmund, king of the Hwicce ( $d$. before 746): see Hwicce, kings of the Æthelred, ruler of the Mercians (d. 911): Marios Costambeys, i.407-8 Æthelred, king of the Mercians (d. after 704): Ann Williams, i.407 Æthelred I, king of Northumbria (d. 796): David Rollason, xlii.97-8 Æthelred I, king of the West Saxons (d. 871): Sean Miller, i.408-9; DNB WH Æthelred II, king of Northumbria (fl. c. 854-c. 862): David Rollason, xvii.563 Æthelred II ('the Unready'), king of the English (c. 966x8-1016): Simon Keynes, i.409-19; $D N B$ WH

Æthelric, king of the Hwicce (fl. c. 693-736): see Hwicce, kings of the Æthelstan, king of the South Saxons (fl. 714?): see South Saxons, kings of the Æthelstan, king of the English (893/4-939): Sarah Foot, i.420-8; DNB Grant Allen

Æthelstan ætheling (d. 1014): Simon Keynes, i.429

*Æthelthryth, queen in Northumbria, consort of King Ecgfrith, and abbess of Ely ( $d$. 679): Alan Thacker, i.429-32; DNB Edmund Venables

Æthelwealh, king of the South Saxons (d. c. 685): see South Saxons, kings of the Æthelwold Moll, king of Northumbria (fl. 759-765): David Rollason, xlii.97 Æthelwulf, king of the West Saxons (d. 858): Janet L. Nelson, i.438-41; DNB WH Aldfrith, king of Northumbria (d. 704/5): Rosemary Cramp, i.618-19; DNB WH Alfred ('the Great'), king of the West Saxons and of the Anglo-Saxons (848/9-899): Patrick Wormald, i.716-25; DNB E. A. Freeman

Alfred ætheling, prince (d. 1036/7): M. K. Lawson, i.727; DNB WH

Alhred, king of Northumbria (fl. 765-774): David Rollason, xlii.97

Anna, king of the East Angles (d. 654?): S. E. Kelly, ii.169

Baldred, king of Kent (fl. c. 823-7): S. E. Kelly, iii.440; DNB WH 


\section{Helen Foxhall Forbes et al.}

*Balthild, queen of the Franks, consort of Clovis II of Neustria (d. c. 680): Janet L. Nelson, iii.618-19; DNB TAA

Beorhtric, king of the West Saxons (d. 802): Heather Edwards, v.314-15; DNB WH

Beornwulf, king of the Mercians (d. 826): S. E. Kelly, v.316-17; DNB WH

Berhtwulf, king of the Mercians (d. 852); S. E. Kelly, v.348-9; DNB WH

*Bertha, queen in Kent, consort of Æthelberht (b. c. $565 ; D N B$ d. in or after 601): Janet L. Nelson, v.479-80; DNB WH

Burgred, king of the Mercians (d. 874?): S. E. Kelly, viii.815-16; DNB WH

Cædwalla, king of the Gewisse (c. 659-89): Barbara Yorke, ix.429; DNB WRWS

Ceawlin, king of the Gewisse (d. 593): Barbara Yorke, x.715-16; DNB WH

Centwine, king of the Gewisse ( $d$. in or after 685): Barbara Yorke, x.814-15; DNB WH

Cenwalh, king of the Gewisse (d.672): Barbara Yorke, x.815; DNB WH

Cenwulf, king of the Mercians (d. 821): M. K. Lawson, x.817

Ceol, king of the Gewisse (d. 597): Barbara Yorke, x.817; DNB WH

Ceolred, king of the Mercians (d. 716): S. E. Kelly, x.819-20; DNB WH

Ceolwulf, king of the Gewisse (d. 611): Barbara Yorke, x.820.

Ceolwulf, king of Northumbria (d. 764): David Rollason, x.820-1; DNB WH

Ceolwulf II, king of the Mercians (fl. 874-9): Sean Miller, x.821

Cerdic, king of the Gewisse (fl. 6th cent.): Barbara Yorke, x.822-3; DNB WH

Cnut, king of England, Denmark and Norway (d. 1035): M. K. Lawson, xii.239-46; $D N B$ WH

Coenred, king of the Mercians (d. after 709): S. E. Kelly, xii.393; DNB Henry Bradley

Cuthred, king of the West Saxons (d. 756): Heather Edwards, xiv.837-8; DNB WH

Cwichelm, king of the Gewisse (d. 636): Barbara Yorke, xiv.857; DNB WH

Cynegils, king of the Gewisse (d. 642): Barbara Yorke, xiv.860; DNB WH

*Cynethryth, queen of the Mercians and abbess of Cookham (fl. c. 770-98): S. E. Kelly, xiv.861-2

Cynewulf, king of the West Saxons (d. 786): Heather Edwards, xiv.863-4; DNB WH Cynric, king of the Gewisse ( $f$. 6th cent.): Barbara Yorke, xiv.867; DNB WH

Eadbald, king of Kent (d. 640): S. E. Kelly, xvii.521-2; DNB WH

Eadberht, king of Northumbria (d. 768): David Rollason, xvii.522-3; DNB WH

Eadberht I, joint king of Kent (d. 748): see Æthelberht II, king of Kent

Eadberht II, joint king of Kent ( $f$. 762-3): see Æthelberht II, king of Kent

Eadberht Præn, king of Kent (fl. 796-8): S. E. Kelly, xvii.523; DNB WH

*Eadburh, queen of the West Saxons (fl. 789-802): Janet L. Nelson, xvii.524; DNB WH

*Eadgifu, queen of the Anglo-Saxons ( $b$. in or before 904; $D N B d$. in or after 966): Pauline Stafford, xvii.527-8

*Eadgifu, queen of the West Franks (d. in or after 951): Janet L. Nelson, xvii.526-7

Eadred, king of the English (d. 955): Ann Williams, xvii.531-4; DNB WH

Eadric, king of Kent (d. 686): see Hlothhere, king of Kent

Eadwig, king of the English (c. 940-59): Simon Keynes, xvii.539-42; DNB WH

Eadwine, king of Northumbria (c. 586-633): Rosemary Cramp, xvii.543-6; DNB WH

*Ealdgyth, queen (fl. c. 1057-66): K. L. Maund, xvii.551; DNB WH 


\section{Anglo-Saxon and related entries in the ODNB (2004)}

Ealdred, leader of the Northumbrians (d. 933?): Benjamin T. Hudson, xvii.551-2

Ealdred, king of the Hwicce (fl. 757-77): see Hwicce, kings of the

Ealdwulf, king of the South Saxons (fl. c. 760): see South Saxons, kings of the

Ealhmund, joint king of Kent (fl. 784): see Æthelberht II, king of Kent

Ealhmund, prince and martyr (d. 800): David Rollason, xvii.554-5

*Ealhswith, consort of Alfred, king of the Anglo-Saxons (d. 902): Marios Costambeys, xvii.555-6

Eanberht, king of the Hwicce (fl. 757-9): see Hwicce, kings of the

*Eanflæd, queen in Northumbria (b. 626, d. after 685): Alan Thacker, xvii.557-8; DNB WH

Eanfrith, king of the Hwicce (fl.c. 670): see Hwicce, kings of the

Eanhere, king of the Hwicce (fl. c. 670): see Hwicce, kings of the

Eanmund, joint king of Kent ( $f$. 763-4): see Æthelberht II, king of Kent

Eanred, king of Northumbria (fl. c. 830-c. 854): David Rollason, xvii.558

Eardwulf, joint king of Kent ( $d$. in or before 762$)$ : see Æthelberht II, king of Kent

Eardwulf, king of Northumbria (fl. 796-c. 830): David Rollason, xvii.562-3

East Saxons, kings of the (act. late 6th cent.-c.820) [group-entry]: Barbara Yorke, xvii.602-4

Ecgberht, king of the West Saxons (d. 839): Heather Edwards, xvii.636-9; DNB WH

Ecgberht I, king of Kent (d. 673): see Eorcenberht, king of Kent

Ecgberht II, joint king of Kent (fl. 765-79): see Æthelberht II, king of Kent

Ecgfrith, king of Northumbria, 645/6-685): J. R. Maddicott, xvii.639-40

Ecgfrith, king of the Mercians (d. 796): see Offa, king of the Mercians

Edgar, king of the English (943/4-975): Ann Williams, xvii.698-703; DNB WH

*Edith, queen (d. 1075): Ann Williams, xvii.738-9; DNB WH

Edmund, king of the East Angles (d. 869): Antonia Gransden, xvii.754-5; DNB William Benham

Edmund I, king of the English (920/21-946): Ann Williams, xvii.766-9; DNB WH

Edmund II, king of the English (d. 1016): M. K. Lawson, xvii.769-70; DNB WH

Edward the Elder, king of the Anglo-Saxons (870s?-924): Sean Miller, xvii.779-83; $D N B W H$

Edward ('the Martyr'), king of the English (c. 962-978): Cyril Hart, xvii.783-5; DNB WH

Edward ('the Confessor'), king of the English (1003x5-1066): Frank Barlow, xvii.78592; $D N B \mathrm{WH}$

Edward ('the Exile'), ætheling (d. 1057): M. K. Lawson, xvii.896-7

*Emma, queen (d. 1052): Simon Keynes, xviii.412-14; DNB WH

Eorcenberht, king of Kent (d. 664): S. E. Kelly, xviii.473

Eormenric, ruler of Kent (fl. 550x600): see Kent, kings of

Erik Bloodaxe, viking leader (d. 954): Marios Costambeys, xviii.497-9

Guthfrith, king of York (b. before 920, d. 934): Cyril Hart, 1.597; DNB F. Y. Powell

Guthrum, king of the East Angles (d. 890): Marios Costambeys, xxiv.322; DNB Kate Norgate

Hálfdan [Healfdene], king of the Danes (d. 877): Marios Costambeys, xxiv.562-3 


\section{Helen Foxhall Forbes et al.}

Harald Hardrada, king of Norway (1015-1066): Claus Krag, xxv.100-1

Harold I [called Harold Harefoot], king of the English (d. 1040): M. K. Lawson, xxv.355-6; DNB WH

Harold II [Harold Godwineson], king of the English (1022/3?-1066): Robin Fleming, xxv.356-62; DNB WH

Harthacnut, king of England and Denmark (c. 1018-1042): M. K. Lawson, xxv.602-3; $D N B \mathrm{WH}$

Heahberht, joint king of Kent (fl. 764): see Æthelberht II, king of Kent

Hengist, king in Kent (d. 488?): see Kent, kings of; DNB C. T. Martin

Hlothhere, king of Kent (d. 685): S. E. Kelly, xxvii.339-40

Horsa, king in Kent (d. 455?): see Kent, kings of; DNB C. T. Martin

Hwicce, kings of the (act.c. 670-c. 780) [group-entry]: Patrick Sims-Williams, xxix.11416

Ine, king of the West Saxons (d. in or after 726): Patrick Wormald, xxix.236-8; DNB WH

*Judith, queen of Wessex (b. after 843; DNB d. c. 870): Janet L. Nelson, i.439-40; DNB WH

*Judith of Flanders, duchess of Bavaria (1030x35-1095): Elisabeth van Houts, xxx.815

Kent, kings of (act. c. 450-c. 590) [group-entry]: Barbara Yorke, xxxi.315-16

*Matilda, queen, consort of William I (d. 1083): Elisabeth van Houts, xxxvii.318-20; $D N B \mathrm{WH}$

Nunna, king of the South Saxons (fl. 692-714?): see South Saxons, kings of the; DNB WH

Octa, king of Kent (fl. 512?): see Kent, kings of; $D N B$ WH

Offa, king of the East-Saxons (fl. 709): see East Saxons, kings of the; $D N B$ WH

Offa, king of the Mercians (d. 796): S. E. Kelly, xli.545-8; DNB WH

Óláf Tryggvason, king of Norway (d. 999): Niels Lund, xli.665-6

Osbald, king of Northumbria (d. 799): David Rollason, xli.979; $D N B \mathrm{WH}$

Osberht, king of Northumbria (d. 867): David Rollason, xli.982-3; DNB CLK

*Osburh, consort of Æthelwulf, king of the West Saxons ( $f$. 839): Janet L. Nelson, xlii.40; $D N B \mathrm{WH}$

Oshere, king of the Hwicce (fl. c. 680-c. 693): see Hwicce, kings of the; DNB WH

Oslac, king of the South Saxons (fl. c. 760): see South Saxons, kings of the

Osmund, king of the South Saxons (fl. 765-770x72): see South Saxons, kings of the; $D N B W H$

Osred I, king of Northumbria (696x8-716): David Rollason, xlii.60-1; DNB WH

Osred II, king of Northumbria (d. 792): David Rollason, xlii.61; DNB WH

Osric, king of Deira (d. 634): D. J. Craig, xlii.61-2; $D N B \mathrm{WH}$

Osric, king of Northumbria (d. 729): D. J. Craig, xlii.62; DNB James Mackinnon

Osric, king of the Hwicce (fl. 674-9): see Hwicce, kings of the

*Osthryth, queen, consort of Æthelred, king of the Mercians (d. 697): S. E. Kelly, xlii.65; $D N B$ Edmund Venables

Oswald, king of Northumbria (603/4-642): D. J. Craig, xlii.76-9; DNB WH

Oswine, king of Deira (d. 651): D. J. Craig, xlii.93-4; DNB CLK 


\section{Anglo-Saxon and related entries in the ODNB (2004)}

Oswiu, king of Northumbria (611/12-670): D. J. Craig, xlii.94-7; DNB WH

Oswulf, king of Northumbria (d. 759): David Rollason, xlii.97-8; DNB WH

Peada, king of the Middle Angles (d. 656): S. E. Kelly, xliii.263; DNB WH

Penda, king of the Mercians (d. 655): S. E. Kelly, xliii.515-16; DNB WH

Rædwald, king of the East Angles (d. 616x27): James Campbell, xlv.786; DNB WH

Rædwulf, king of Northumbria (d. c. 858): David Rollason, xvii.563

Ragnall, king of York (d. 920/21): Cyril Hart, xlv.796

Sæbbi, king of the East Saxons (d. 693/4): see East Saxons, kings of the; DNB WH

Sæberht, king of the East Saxons (d. 616/17): see East Saxons, kings of the; DNB WH

Sæward, king of the East Saxons (d. in or after 617): see East Saxons, kings of the

*Seaxburh, queen of the Gewisse (d. 674?): Barbara Yorke, xlix.616; DNB WH

*Seaxburh, queen of Kent; consort of King Eorcenberht, and abbess of Ely $(b$. in or before 655, d. c. 700): David Rollason, xlix.616; $D N B$ WH

Seaxred, king of the East Saxons (d. in or after 617): see East Saxons, kings of the; $D N B$ WH

Selered, king of the East Saxons (d. 746): see East Saxons, kings of the; DNB WH Sigeberht, king of the East Angles (fl. 630/31-654): James Campbell, 1.592; DNB WH

Sigeberht, king of the West Saxons (d. 757): Heather Edwards, 1.592-3; DNB WH

Sigeberht I, king of the East Saxons (fl. 626): see East Saxons, kings of the; $D N B$ WH

Sigeberht II, king of the East Saxons (fl. c. 653): see East Saxons, kings of the; $D N B$ WH

Sigeheard, king of the East Saxons (fl. 693/4): see East Saxons, kings of the; DNB WH Sigehere, king of the East Saxons (fl. 663-4): see East Saxons, kings of the; DNB WH Sigered, king of the East Saxons ( $f$. 811): see East Saxons, kings of the; $D N B$ WH Sigered, joint king of Kent (fl. 762-5): see Æthelberht II, king of Kent

Sigeric, king of the East Saxons ( $d$. in or after 798): see East Saxons, kings of the

Sihtric Cáech, king of York (d. 927): Cyril Hart, 1.597; DNB F. Y. Powell

South Saxons, kings of the (act. 477-772) [group entry]: S. E. Kelly, li.702-3

Sutton Hoo burial, king or aristocrat (early 7 th cent.): James Campbell, liii.416-17

Swæfbert, king of the East Saxons (d. 738): see East Saxons, kings of the

Swæfred, king of the East Saxons ( $f$. 693/4): see East Saxons, kings of the

Swein, king of England and of Denmark (d. 1014): P. H. Sawyer, liii.453-5; DNB WH

Swithhelm, king of the East Saxons (d. 663): see East Saxons, kings of the

Swithred, king of the East Saxons (fl. c. 746): see East Saxons, kings of the

Uhtred, king of Hwicce ( $f$. 757-777): see Hwicce, kings of the

Watt, king of South Saxons ( $f$. 692): see South Saxons, kings of the

Wiglaf, king of the Mercians (fl. 827-c. 840): S. E. Kelly, lviii.853-4; DNB AMC

Wihtgar, king of Wight (d. 544?): Barbara Yorke, lviii.863; DNB AMC

Wihtred, king of Kent (d. 725): S. E. Kelly, lviii.864; DNB AMC

William I ('the Conqueror'), king of England (1027/8-87): David Bates, lix.45-57; $D N B$ WH

Wulfhere, king of the Mercians (d. 675): S. E. Kelly, lx.550-1; DNB Mary Tout 


\section{Helen Foxhall Forbes et al.}

\section{b. Ecclesiastics}

Abbo of Fleury, abbot of St Benoît-sur-Loire (945x50-1004): Richard W. Pfaff, i.1011

Acca, bishop of Hexham (d. 740): Alan Thacker, i.133; DNB Mandell Creighton

Adalbert, missionary (supp. fl. early 8th cent.): Marios Costambeys, i.190; DNB T. A. Archer

*Æbbe, abbess of Coldingham (d. 683?): Alan Thacker, i.372-3; DNB WH

Ælberht, archbishop of York (d. 779/80): David Rollason, i.378-9

*Elfflæd, abbess of Strensall-Whitby (654-714): Alan Thacker, i.379-80; DNB WH

Ælfheah, archbishop of Canterbury (d. 1012): Henrietta Leyser, i.382-3; DNB WH

Ælfric, archbishop of Canterbury (d. 1005): Emma Mason, i.385; DNB WH

Ælfric, archbishop of York (d. 1051): rev. Marios Costambeys, i.386; DNB WH

Ælfric Bata, monk and author (fl. c. 1010): Malcolm Godden, i.388; DNB WH

Elfric of Eynsham, homilist and abbot (c. 950-c. 1010): Malcolm Godden, i.387-8; $D N B$ WH

Ælfsige, archbishop of Canterbury (d. 959): Barbara Yorke, i.388-9; DNB WH

[Ælfsige] Aelsinus, monk and scribe of the New Minster, Winchester ( $f$. c. 1023-c. 1031): Richard Gameson, i.393; DNB W. C. Monkhouse

Ælfweard, abbot of Evesham, bishop of London (d. 1044): rev. Marios Costambeys, i.390-1; DNB WH

Ælfwig, abbot of New Minster, Winchester (d. 1066): rev. Marios Costambeys, i.391; $D N B W H$

Ælfwine, bishop of Winchester (d. 1047): Emma Mason, i.391; DNB WH

Ælric, archbishop-elect of Canterbury (fl. 1050-1): rev. Marios Costambeys, i.392-3; $D N B W H$

*Æthelburh, abbess of Barking (fl. 664): Marios Costambeys, i.401; DNB WH

Æthelgar, archbishop of Canterbury (d. 990): rev. Mary Frances Smith, i.404; $D N B$ WH

Æthelheard, archbishop of Canterbury (d. 805): Ann Williams, i.405-6; DNB WH

Æthelnoth, archbishop of Canterbury (d. 1038): Emma Mason, i.406-7; DNB WH

Æthelred, archbishop of Canterbury (d. 888): A. F. Wareham, i.407; DNB WH

Æthelric, bishop of Dorchester (d. 1034): Emma Mason, i.419-20

Æthelwold, abbot of Abingdon, bishop of Winchester (d. 984): Barbara Yorke, i.434-8; $D N B \mathrm{WH}$

Agilbert, bishop of the West Saxons (d. 679x90): Paul Fouracre, i.457-8

Ailnoth [Ælnoth], Benedictine monk and hagiographer (fl. c. 1085- c. 1122): L. Abrams, i.490-1; DNB Alexander Gordon

Albinus, abbot of St Peter's and St Paul's, Canterbury (d. 732): Marios Costambeys, i.587-8; DNB C. F. Keary

Alcuin, abbot of St Martin's, Tours, and royal adviser (c. 740-804): D. A. Bullough, i.602-8; DNB Robert Adamson

Aldhelm, abbot of Malmesbury, bishop of Sherborne, and scholar (d. 709/10): Michael Lapidge, i.619-23; DNB WH

Aldhun, bishop of Durham (d. 1018): David Rollason, i.623-4; DNB WH 


\section{Anglo-Saxon and related entries in the ODNB (2004)}

Aldred, provost of Chester-le-Street and glossator (fl. c. 970): Janet Backhouse, i.628; $D N B$ E. M. Thompson

Alhmund, bishop of Hexham (d. 781): rev. Marios Costambeys, i.731; DNB WH

Anselm, abbot of Bec. archbishop of Canterbury (c. 1033-1109): R. W. Southern, ii.247-58; $D N B$ WRWS

Athelm, archbishop of Canterbury (d. 926): Emma Mason, ii.806; DNB WH

Augustine, missionary, archbishop of Canterbury (d. 604): Henry Mayr-Harting, ii.948-50; $D N B$ Mandell Creighton

Baldred, bishop (d. 608?): see Balthere, hermit; DNB TFT

Balthere, hermit (d. 756): D. H. Farmer, iii.617-18; DNB T. F. Henderson

Beadwulf, bishop of Whithorn (fl. 791-5): rev. Marios Costambeys, iv.504; DNB TFT

Bede, monk, historian, and theologian (673/4-735): James Campbell, iv.758-65; DNB WH

*Bega, abbess of Hartlepool (supp. $f$. late 7th cent.): Robert Bartlett, iv.834; DNB WRWS

Benedict Biscop, abbot of Wearmouth (c. 628-89): S. J. Coates, v.64-6; DNB WRWS

Beornred, archbishop of Sens, abbot of Echternach (d. 797): Marios Costambeys, v.316

Berhthun, abbot (probably of Beverley): (d. 733/40): rev. D. M. Palliser, v.347-8; DNB Henry Bradley

Berhtwald, archbishop of Canterbury (c. 650-731): rev. Henrietta Leyser, v.348; DNB WRWS

Bernard, cleric and traveller (fl. c. 865-70): David Ganz, v.417; DNB Henry Bradley

Billfrith, anchorite (d.750x800?): David Rollason, v.720; DNB E. M. Thompson

Birinus, bishop of Dorchester (d. c. 650): Barbara Yorke, v.831; DNB E. M. Thompson

Boisil, prior of Melrose (d. c. 661): Alan Thacker, vi.452; DNB [Anon.]

Boniface, archbishop of Mainz, missionary (672x5?-754): I. N. Wood, vi.540-5; DNB

E. M. Thompson

Bosa, bishop of York (d. 706): Alan Thacker, vi.687; DNB WH

Botwulf, abbot of Iken (fl. 654-c.670): John Blair, vi.773; DNB Arthur H. Grant

Bregowine, archbishop of Canterbury (d. 764): Ann Williams, vii.435; DNB WH

Brihtwold, abbot of Glastonbury and bishop of Ramsbury (d. 1045): rev. Marios Costambeys, vii.655; $D N B$ W. R. W. Stephens

*Bugga, abbess ( $f$. late 7th- early 8th cent.): Barbara Yorke, viii.566-7

*Bugga [Hæaburh], abbess (d. 759x65): Barbara Yorke, viii.567

Burchard, bishop (d. 753): Marios Costambeys, viii.725-6

*Burginda, author (fl. 7th-early 8th cent.): Patrick Sims-Williams, viii.803

Byrhtferth of Ramsey, monk and scholar (fl.c.986-c.1016): Michael Lapidge, ix.332-3; DNB Henry Bradley

Byrhtnoth, abbot of Ely (d. 996): A. F. Wareham, ix.335

Byrnstan, bishop of Winchester (d. 934): Barbara Yorke, ix.340; DNB TFT

Cædmon, poet (fl. c. 670): E. G. Stanley, ix.427-8; DNB Henry Bradley

Candidus, theologian (fl. 793-802): John Marenbon, ix.888-9 


\section{Helen Foxhall Forbes et al.}

Ceadda, abbot of Lastingham, bishop of Mercia and Lindsey (d. 672?): D. H. Farmer, x.713-14; $D N B$ W. R. W. Stephens

Cedd, bishop of East Saxons (d. 664): D. H. Farmer, x.800-1; DNB TFT

Cenwulf, abbot of Peterborough, bishop of Winchester (d. 1006): rev. Henrietta Leyser, x.815-17; $D N B$ WH

Ceolfrith, abbot of Wearmouth and Jarrow (642-716): S. J. Coates, x.817-19; DNB WH

Ceolnoth, archbishop of Canterbury (d. 870): A. F. Wareham, x.819; DNB WH

*Christina, princess and nun (fl. 1057-93): Nicholas Hooper, xi.584; DNB TFT

Cuthbert, archbishop of Canterbury (d. 760): Ann Williams, xiv.834-6; DNB WH

Cuthbert, bishop of Lindisfarne (c. 635-87): David Rollason and R. B. Dobson, xiv.829-34; $D N B$ WH

*Cuthburh, supposed abbess of Wimborne (fl. c. 700-18): Barbara Yorke, xiv.837; $D N B$ WH

*Cwenthryth, abbess (fl. 811-c.827): S. E. Kelly, xiv.856-7

Cynehelm, martyr (supp. fl. 803x11): David Rollason, xiv.860-1

Cynesige, archbishop of York (d. 1060): Janet Cooper, xiv.861; DNB WH

Cynewulf, poet (fl. 9th cent.): E. G. Stanley, xiv.863-4; DNB L. T. Smith

Cyngar, holy man (supp. fl. early 8th cent.): Marios Costambeys, xiv.864-5; DNB WH

Daniel, bishop of Winchester (d. 745): Barbara Yorke, xv.63; DNB Edmund Venables

Denewulf, bishop of Winchester (d. 908): Barbara Yorke, xv.770-1

Deusdedit, archbishop of Canterbury (d. 664): Alan Thacker, xv.929; DNB T. A. Archer

Dunstan, archbishop of Canterbury (d. 988): Michael Lapidge, xvii.347-53; DNB WH

Eadberht, bishop of Lindisfarne (d. 698): Alan Thacker, xvii.522; DNB WH

*Eadburh, abbess (probably of Wimborne): (fl. c. 716-46): Barbara Yorke, xvii.523-4

*Eadburh, nun (921x4-951x3): Barbara Yorke, xvii.524-5

*Eadburh, abbess of Thanet (d. 751): Barbara Yorke, xvii.523; DNB WH

Eadfrith, bishop of Lindisfarne (d. 721?): Alan Thacker, xvii.526; DNB TFT

Eadsige, archbishop of Canterbury (d. 1050): rev. Mary Frances Smith, xvii.539; DNB WH

Eadwig Basan, monk and scribe (fl. c. 1020): Richard Gameson, xvii.542-3

Ealdred, archbishop of York (d. 1069): M. K. Lawson, rev. Vanessa King, xvii.552-4

Ealdwulf, archbishop of York (d. 1002): rev. Mary Frances Smith, xvii.554; DNB WH

Eanbald (I): archbishop of York (d. 796): David Rollason, xvii.556-7; DNB WH

Eanbald (II): archbishop of York (fl. 796-803): David Rollason, xvii.557; DNB WH

Earconwald, abbot of Chertsey, bishop of the East Saxons (d. 693): Patrick Wormald, xvii.559-60; DNB WH

Eata, bishop of Hexham (d. 685/6): Alan Thacker, xvii.605-6; DNB WH

Ecgberht, archbishop of York (d. 766): Henry Mayr-Harting, xvii.635-6; DNB WH

Ecgberht, church reformer (639-729): Henry Mayr-Harting, xvii.634-5; DNB TFT

*Ecgburh, nun (fl. c. 717): Patrick Sims-Williams, xvii.639

Ecgwine, bishop of Worcester (d. 717): Michael Lapidge, xvii.640-1

*Edith, nun (961x4-984x7): Barbara Yorke, xvii.737-8; DNB WH 


\section{Anglo-Saxon and related entries in the ODNB (2004)}

Ernulf, bishop of Rochester (1039/40-1124): P. Cramer, xviii.511-12; DNB R. L. Poole

*Eve of Wilton, Benedictine nun and anchoress (c. 1058-c. 1125): Henrietta Leyser, lix. 667

Felix, bishop of the East Angles (d. 647/8): Marios Costambeys, xix.253; DNB Mandell Creighton

Feologeld, archbishop of Canterbury (d. 832): rev. Marios Costambeys, xix.334; DNB $\mathrm{WH}$

Florence of Worcester, monk and chronicler (d. 1118): P. McGurk, lx.292; DNB WH

Folcard, monk, musician and hagiographer (d. after 1085): Frank Barlow, xix.204-5; $D N B \mathrm{WH}$

Fredericus, bishop of Utrecht (d. 838): Marios Costambeys, xix.914-15; DNB Henry Bradley

Fridugisus, abbot and scholar (d. 833): Mary Garrison, xx.27-8

Frithegod, cleric and poet (fl. c. 950-8): Michael Lapidge, xx.49; DNB WH

Frithestan, bishop of Winchester (d. 932/3): Barbara Yorke, xx.49-50

*Frithuswith, abbess of Oxford (d. 727): John Blair, xx.50-1; DNB WH

Giso, bishop of Wells (d. 1088): Julia Barrow, xxii.358-9; DNB WH

Godfrey of Winchester, poet and prior of Winchester (b. before 1055, d. 1107): A. G. Rigg: lix.688-9; DNB CLK

Goscelin, monk, musician, and hagiographer (b. c. 1035, d. in or after 1107): Frank Barlow, xxii.1020-1; DNB T. A. Archer,

Grimbald, monk, musician, and hagiographer (d. 901?): Richard W. Pfaff, xxiv.19-20; $D N B \mathrm{WH}$

Guthlac, hermit (674-715): Henry Mayr-Harting, xxiv.301-2; DNB Kate Norgate

Hadrian, abbot of St Peter's and St Paul's, Canterbury (630x7-709): Michael Lapidge, xxiv.437-8

Hædde, bishop of Winchester (d. 705/6): Barbara Yorke, xxiv.439-40; DNB WH

Haimo [Haymo], archdeacon of Canterbury (supp. fl. 1054): Peter Damian-Grint, xxiv.479; $D N B$ CLK

Hereberht, hermit (d. 687): rev. Marios Costambeys, xxvi.763; DNB CLK

Hermann, Benedictine monk and hagiographer (fl. 1070-1100): Antonia Gransden, xxvi.787-8; DNB WH

Hermann, bishop of Ramsbury and of Sherborne (d. 1078): Julia Barrow, xxvi.787-8; $D N B \mathrm{WH}$

*Hild, abbess of Strensall-Whitby (614-80): Alan Thacker, xxvii.90-1; DNB Edmund Venables

*Hildelith, abbess of Barking (fl. c. 700): Michael Lapidge, xxvii.91-2; DNB CLK

Honorius, archbishop of Canterbury (d. 653): rev. N. P. Brooks, xxvii.910-11; DNB WH

*Hugeburc, nun and hagiographer (fl. 760-80): Carolyne Larrington, xxviii.599-600

Hygbald, bishop of Lindisfarne (d. 802/3): Mary Garrison, xxix.158-9

Hygeberht, archbishop of Lichfield (d. in or after 803): Ann Williams, xxix.160; DNB WH 


\section{Helen Foxhall Forbes et al.}

Ingulf, abbot of Crowland (c. 1045-1109): Edmund King, xxix.294-5; DNB WH Jænberht, archbishop of Canterbury (d. 792): Marios Costambeys, xxix.580; DNB WH John of Beverley, bishop of York (d. 721): D. M. Palliser, xxx.193-4; DNB WH John the Old Saxon, scholar and abbot of Athelney (fl. c. 885-904): Michael Lapidge, xxx.204

Justus, archbishop of Canterbury (d. 627x31): rev. N. P. Brooks, xxx.845-6; DNB WH Lantfred, monk and author (fl. 974-84): Michael Lapidge, xxxii.545-6; DNB CLK Laurence, archbishop of Canterbury (d. 619): N. P. Brooks, xxxii.691; DNB WH Lebuin, missionary (d. c. 775): Marios Costambeys, xxxiii.22-3; DNB WH *Leoba, abbess of Tauberbischofsheim (d. 782): Barbara Yorke, xxxiii.394-5 Leofric, bishop of Exeter (d. 1072): Frank Barlow, xxxiii.397; DNB WH Leofric, priest and rebel (fl. 1070-1071): David Roffe, xxvi.767; DNB MB Leuthere, bishop of Winchester (d. 675/6): Paul Fouracre, xxxiii.516 Lul, archbishop of Mainz (c. 710-786): Marios Costambeys, xxxiv.740-1 Lyfing, abbot of Tavistock, bishop of Worcester (d. 1046): Barlow Frank, xxxiv.858; $D N B W H$

Lyfing, archbishop of Canterbury (d. 1020): Emma Mason, xxxiv.857-8; DNB WH Mannig, abbot of Evesham and craftsman (d. 1066): John Blair, xxxvi.483-4 Mellitus, archbishop of Canterbury (d. 624): N. P. Brooks, xxxvii.751-2; DNB MB *Mildburg, abbess of Much Wenlock (d. in or after 716): John Blair, xxxviii.111-12; $D N B \mathrm{WH}$

*Mildrith, abbess of Minster in Thanet (fl. 716-c. 733): David Rollason, xxxviii.126-7; $D N B$ WH

Milred, bishop of Worcester (d. 774/5): Patrick Sims-Williams, xxxviii.330; DNB WH Nothhelm, archbishop of Canterbury (d. 739): rev. Henry Mayr-Harting, xli.212-13; $D N B$ WH

Oda, archbishop of Canterbury (d. 958): Catherine Cubitt and Marios Costambeys, xli.484-7; $D N B \mathrm{WH}$

Oftfor, bishop of Worcester (d. c. 699): Patrick Sims-Williams, xli.556-7; DNB MB

Oscytel, archbishop of York (d. 971): Julia Barrow, xlii.41-2; DNB MB

Osgar, abbot of Abingdon (d. 984): rev. Marios Costambeys, xlii.42; DNB MB

*Osgyth, abbess of Chich ( $f$. late 7th cent.): John Blair, xlii.45-6; $D N B$ WH

Osmund, bishop of London (d. 805x11): rev. Marios Costambeys, xlii.58; DNB WH

Oswald, archbishop of York (d. 992): N. P. Brooks, xlii.79-84; DNB WH

Oswald, monk and scholar (fl. 1006-1042): Michael Lapidge, xlii.84; DNB MB

Paulinus, bishop of York and of Rochester (d. 644): Marios Costambeys, xliii.166-8; $D N B W H$

Pehthelm, bishop of Whithorn (d. 735): rev. Marios Costambeys, xliii.441; DNB MB

Pehtwine, bishop of Whithorn (d. 776/7): rev. Marios Costambeys, xliii.441; DNB MB

Petronius, abbot of St Peter's and St Paul's, Canterbury (d. 654?): rev. Marios Costambeys, xliii.927-8; $D N B$ WH

Petrus, abbot of St Peter's and St Paul's, Canterbury (d. 605x11): rev. Marios Costambeys, xliii.928-9; $D N B$ WH

Plegemund, archbishop of Canterbury (d. 914): A. F. Wareham, xliv.574-5; DNB WH 


\section{Anglo-Saxon and related entries in the ODNB (2004)}

Putta, bishop (d. c. 688): Patrick Sims-Williams, xlv.601-2; DNB WH

Regenbald, priest and chancellor (fl. 1050-86): Mary Frances Smith, xlvi.364-5; DNB J. H. Round

Robert of Jumièges, archbishop of Canterbury (d. 1052/1055): H. E. J. Cowdrey, xlvii.122-3; DNBWH

Rodulf, missionary bishop, abbot of Abingdon (d. 1052): L. Abrams, xlvii.506

Romanus, bishop of Rochester ( $d$. in or before 627): rev. Marios Costambeys, xlvii.656; $D N B$ C. R. Beazley

Seaxwulf, abbot of Peterborough, bishop of Lichfield (d. 692): John Blair, xlix.617; $D N B \mathrm{WH}$

Sigeric, archbishop of Canterbury (d. 994): Emma Mason, 1.593; DNB WH

Sigfrid, co-abbot of St Peter's, Wearmouth (d. 689): rev. Marios Costambeys, 1.593-4; $D N B W H$

Sigfrid, missionary bishop ( $f$. mid-10th-early 11 th cent.): L. Abrams, 1.594

Stigand, archbishop of Canterbury (d. 1072): H. E. J. Cowdrey, lii.774-7; DNB WH

Siward, abbot of Chertsey, bishop of Rochester (d. 1075): rev. Marios Costambeys, 1.813-14; DNB WH

Siward, bishop and coadjutor-archbishop (d. 1048): rev. Marios Costambeys, 1.812; $D N B$ WH

Spearhafoc, abbot of Abingdon (fl. 1047-1051): John Blair, li.761-2

Stephen of Ripon, priest (fl. c. 670-c. 730): Alan Thacker, lii.423-4; DNB WH

Sualo, hermit (d. 794): Marios Costambeys, liii.261; DNB CLK

Sulcard, monk of Westminster (fl. c. 1080): Barbara F. Harvey, liii.292; DNB MB

Swithberht, bishop and missionary (d. 713): Marios Costambeys, liii.523; DNB MB

Swithun, bishop of Winchester (d. 863): Barbara Yorke, liii.523-5; DNB WH

Tatwine, archbishop of Canterbury (d. 734): Michael Lapidge, liii.831-2; DNB WH

Theodore of Tarsus, archbishop of Canterbury (602-90): Michael Lapidge, liv.226-30; $D N B W H$

Thurcytle, abbot of Crowland (d. 975?): C. P. Lewis, liv.709; DNB AMC

Tidferth, bishop of Dunwich (d. 816x24): rev. Marios Costambeys, liv.765; DNB AFP

Tobias, bishop of Rochester (d. 726): rev. Marios Costambeys, liv.854; DNB AFP

Turgot, bishop of St Andrews and hagiographer (c. 1050-1115): Robert Bartlett, lv.577-8; DNB G. W. Sprott

Unwona, bishop of Leicester (d. 800x3): rev. Marios Costambeys, lv.921; DNB AFP

*Walburg, abbess of Heidenheim (c. 710-79?): Carolyne Larrington, lvi.758; DNB MB

Waldhere, bishop of the East Saxons (fl. 694-704/5): Marios Costambeys, lvi.781-2; $D N B W H$

Walkelin, bishop of Winchester (d. 1098): M. J. Franklin, lvi.805-6; DNB WH

Walter, bishop of Hereford (d. 1079?): Julia Barrow, lvii.156; DNB WH

*Werburh, abbess (d. 700x7): Alan Thacker, lviii.164-5; DNB WH

Werferth, bishop of Worcester (d. 907x15): Richard W. Pfaff, lviii.166-7; DNB AMC

Wigheard, archbishop-elect of Canterbury $(d .664 \times 7)$ : rev. Marios Costambeys, lviii.842; $D N B \mathrm{MB}$

Wigstan, martyr (d. 849): David Rollason, lviii.863 


\section{Helen Foxhall Forbes et al.}

Wilfrid, bishop of Hexham (c. 634-709/10): Alan Thacker, lviii.944-50; DNB WH

Willehad, bishop of Bremen (d. 789): Marios Costambeys, lix.16; DNB AMC

William, bishop of London (d. 1075): Julia Barrow, lix.32-3; DNB WH

William of Jumièges, monk and author ( $f$. 1026-70): Elisabeth van Houts, xxx.828

Willibald, bishop of Eichstätt (c. 700-787?): Carolyne Larrington, lix.363; DNB AMC

Willibrord, abbot of Echternach (657/8-739): Marios Costambeys, lix.363-8; DNB Mary Tout

Wine, bishop (fl. c. 660-c. 675): Barbara Yorke, lix.716; DNB WH

Winnebald, abbot of Heidenheim (c. 702-61): Carolyne Larrington, lix.746

Withman, abbot of Ramsey (d. c. 1047): C. P. Lewis, lix.890; DNB AMC

Wulfhelm, archbishop of Canterbury (d. 941): Henrietta Leyser, 1x.550; DNB WH

*Wulfhild, abbess of Barking and Horton (d. after 996): Barbara Yorke, lx.551-2

Wulfred, archbishop of Canterbury (d. 832): N. P. Brooks, lx.552-4; DNB WH

Wulfsige, bishop of Sherborne (d. 1002x4): Julia Barrow, lx.555-6

Wulfstan, archbishop of York (d. 955/6): Cyril Hart, lx.557-8

Wulfstan, archbishop of York (d. 1023): Patrick Wormald, lx.558-62; DNB WH

Wulfstan, bishop of Worcester (c. 1008-95): Emma Mason, 1x.562-4; DNB WH

Wulfstan Cantor, monk, hagiographer and poet (fl. 996): Michael Lapidge, lx.564-5; $D N B \mathrm{MB}$

*Wulfthryth, abbess of Wilton (d. c. 1000): Barbara Yorke, lx.565

Wulfwig, bishop of Dorchester (d. 1067): Julia Barrow, lx.566-7; DNB AMC

\section{c. Secular men and women}

Ælfgar, earl of Mercia (d. 1062?): Ann Williams, i.380; DNB WH

Ælfheah, ealdorman (d. 971): Ann Williams, i.384

Ælfhere, ealdorman of Mercia (d. 983): Ann Williams, i.383-5; DNB WH

[Ælfmær or Æthelmær] Eilmer, pioneer of man-powered flight (b.c. 985, d. after 1066):

R. M. Thomson, xvii.1022-3; DNB WH

Ælfric, ealdorman (d. 1016): Ann Williams, i.385-6; DNB WH

Ælfric Cild, magnate (fl. 975-85): Ann Williams, i.384

Ælfstan of Boscombe, nobleman (fl. 1043-65): Ann Williams, i.389

Æthelstan ('Half-King'), ealdorman (fl. 932-56/7): Cyril Hart, i.428-9; DNB WH

Æthelweard, ealdorman and chronicler (d. 998?): Patrick Wormald, i.432-3; DNB WH

Æthelwine, ealdorman, founder of Ramsey Abbey (d. 992): Cyril Hart, i.433-4; DNB WH

Aio, supposed historian (supp. fl. 950x75): rev. Marios Costambeys, i. 510; DNB C. F. Keary

Asgar the staller, nobleman (d. after 1066): Ann Williams, ii.596-7

Bald, supposed physician and medical writer (fl. c. 900): M. L. Cameron, iii.436

Baldwin, magnate (d. 1086x90): Judith A. Green, iii.441; DNB WH

Beorhtric, magnate ( $d$. in or before 1066?): Ann Williams, v.315

Beorn Estrithson, magnate (d. 1049): Ann Williams, v.315-16; DNB WH

Brorda, ealdorman (d. 799): Alan Thacker, vii.954-5

Byrhtnoth, ealdorman (d. 991): Richard Abels, ix.333-5; DNB WH 


\section{Anglo-Saxon and related entries in the ODNB (2004)}

Copsi, earl of Northumbria, magnate (d. 1067): William M. Aird, xiii.377; DNB WH

*Eadgifu the Fair, magnate (fl. 1066): Ann Williams, xvii.528

Eadnoth the staller (d. 1068): Ann Williams, xvii.531; DNB WH

Eadric of Laxfield, magnate (d. in or after 1066?): Ann Williams, xvii.534-5

Eadric Streona, ealdorman of Mercia (1007-17): Simon Keynes, xvii.535-8; DNB WH

Eadric the Wild, magnate (fl. 1067-72): Ann Williams, xvii.538-9; DNB WH

Eadwine, earl of Mercia (d. 1071): Ann Williams, i.380

Eilmer, see [Ælfmær]

Erik of Hlathir, earl of Northumbria (fl. 995-1023): Pauline Stafford, xviii.499-500

Eustace, count of Boulogne (d. c. 1087): Edmund King, xviii.648-9

*Godgifu, noblewoman (d. 1067?): Ann Williams, xxii.574-6; DNB Alexander Gordon

Godwine, earl of Wessex (d. 1053): Ann Williams, xxii.626-9; DNB WH

Gospatric, earl of Northumbria (d. 1073x5): William M. Aird, xxii.1033-4; DNB WH

Guy of Warwick, legendary hero (supp. fl. c. 930): Douglas Gray, xxiv.328-9; DNB

Sidney Lee

Gyrth, earl of East Anglia (d. 1066): Ann Williams, xxiv.377-8; DNB WH

*Gytha, wife of Earl Godwine of Wessex (fl. c. 1022-68): Ann Williams, xxii.628-9; $D N B$ WH

Hæsten, viking leader (fl. 882-93): Janet L. Nelson, xxiv.440-1

Hereward [called Hereward the Wake], rebel (fl. 1070-1): David Roffe, xxvi.767-8; $D N B$ TFT

Leofric, earl of Mercia, magnate (d. 1057): Ann Williams, xxxiii.395-7; DNB WH

Leofwine, earl (d. 1066): Ann Williams, xxxiii.397-8; DNB WH

Morcar, magnate (fl. 1065-87): William M. Aird, xxxix.10-11; DNB WH

Odda, magnate (d. 1056): Ann Williams, xli.491-2; DNB CLK

Ohthere, sea-farer (fl. 871-99): Niels Lund, xli.639; DNB C. R. Beazley

Ordgar, landholder (d. 1094?): C. P. Lewis, xli.923; DNB MB

Ordgar, landowner (fl. 1066): C. P. Lewis, xli.923; $D N B$ MB

Ordgar, magnate (d. 971): C. P. Lewis, xli.922-3; DNB MB

Osbern fitz Richard, landowner (fl. c. 1066-88): see Richard Scrob

Osgod Clapa, landowner and exile (d. 1054): Ann Williams, xlii.42-3; DNB CLK

Oslac, ealdorman (fl. 963-75): Cyril Hart, xlii.51; DNB WH

Osulf, magnate (d. 1067): William M. Aird, xlii.72; $D N B$ WH

Ralph, earl (d. 1097x9): Ann Williams, xlv.869-70; DNB CLK

Ralph, earl of Hereford (d. 1057): Ann Williams, xlv.868-9; DNB WH

Ralph the Staller, earl of East Anglia (d. 1068x70): Ann Williams, xlv.873

Richard Scrob, landowner (fl. 1052-66): C. P. Lewis, xlvi.756-7; DNB CLK

Robert fitz Wimarc, magnate (d. c. 1070): Ann Williams, xlvii.121-2; DNB J. H. Round

Sihtric inn Gamli, viking leader (d. 871): Marios Costambeys, 1.597; DNB F. Y. Powell

Sihtric inn Ungi, viking leader (d. 871): Marios Costambeys, 1.597; DNB F. Y. Powell

Siward, earl of Northumbria (d. 1055): William M. Aird, 1.812-13; DNB WH

Swein, earl (d. 1052): Ann Williams, liii.455-6; DNB WH

Thorkell the Tall, viking leader ( $f$. 1009-23): Richard Abels, liv.586-7; DNB AMC

Tostig, magnate (c. 1029-66): William M. Aird, lv.67-9; DNB WH 


\section{Helen Foxhall Forbes et al.}

Tovi the Proud, nobleman (fl. 1018-42): Ann Williams, lv.99-100

Uhtred, earl of Bamburgh (d. 1016): William M. Aird, lv.863-4; DNB WH

Ulf Fenisc, magnate (fl. 1066): P. H. Sawyer, lv.864

Ulfcytel, earl of East Anglia (d. 1016): Richard Abels, lv.865; DNB WH

Waltheof, earl of Northumbria (c. 1050-76): C. P. Lewis, lvii.187-9; DNB WH

Wulfric Spot, founder of Burton Abbey (d. 1002x4): P. H. Sawyer, lx.555; DNB AFP

Wulfstan, sea-farer (fl. 880): Tony D. Triggs, lx.556-7

Wulfweard White, landowner (d. 1072x86): Ann Williams, lx.565-6

\section{3. 'BRITISH' SUBJECTS (c. 400-c. 600)}

\section{a. Kings, consorts and other rulers}

Arthur, legendary warrior and supposed king of Britain (supp. $f$. in or before 6th cent.): O. J. Padel, ii.529-43; DNB C. F. Keary

Brochfael Ysgithrog, king of Powys (supp. fl. 6th cent.): T. M. Charles-Edwards, vii.742-3; $D N B$ WH

Brychan Brycheiniog, king of Brycheiniog (fl. c. 500): David E. Thornton, viii.412-13

Cadell Ddyrnllug, king of Powys ( $f$. 5th cent.): David E. Thornton, ix.402

Constantine III, Roman emperor proclaimed in Britain (d. 411): R. S. O. Tomlin, xiii.33-5

Cunedda, ruler in north Wales (supp. fl. late 4th-5th cent.): Patrick Wormald, xiv.65

Gwallawg, king in Britain (fl. 572x9-585x92): T. M. Charles-Edwards, xxiv.336

Llwyarch Hen, legendary hero (supp. $f$. late 6th cent.): Jenny Rowland, xxxiv.180; DNB DLT

Mynyddog Mwynfawr, king in Britain (supp. fl. 6th cent.): T. M. Charles-Edwards, xl.87 Rhun Hir, king of Gwynedd (fl. 547-c. 600): David E. Thornton, xlvi.611-12; DNB JEL

Rhydderch Hen, king of Strathclyde (fl. c. 573-c. 612): David E. Thornton, xlvi.613; $D N B$ JEL

Uther Pendragon, supposed king of Britain (supp. fl. late 5th cent.?): O. J. Padel, ii.534; $D N B$ C. F. Keary

Vorteporius, king of the Demetae (fl. c. 540): T. M. Charles-Edwards, lvi.594-5

Vortigern, ruler in Britain (fl. 5th cent.): David E. Thornton, lvi.598-9; DNB JEL

\section{b. Ecclesiastics}

Asaf, bishop (supp. fl. 6th cent.): David E. Thornton, ii.584-5; DNB DLT

Brynach, founder of the church of Nevern, Pembrokeshire ( $f$. 6th cent.): T. M. Charles-Edwards, viii.429-30

Cadfan, founder of a religious settlement (supp. fl. 6th cent.): T. M. Charles-Edwards, ix.408; $D N B$ Arthur Miller

Cadog, founder and abbot of Llancarfan (fl. 6th cent.): T. M. Charles-Edwards, ix.41012; DNB Arthur Miller 


\section{Anglo-Saxon and related entries in the ODNB (2004)}

Chrysanthus, bishop of Byzantium ( $f$. 395): see Roman officials (in section 3c)

Cybi, founder of churches ( $f$. 6th cent.): T. M. Charles-Edwards, xiv.857; $D N B$ TFT

Cynidr, founder of churches ( $f$. 6th cent.): T. M. Charles-Edwards, xiv.866-7

David, patron saint of Wales (d. 589/601): J. Wyn Evans, xv.277-82; DNB Henry Bradley

Deiniol, bishop of Bangor (d. 584): T. M. Charles-Edwards, xv.696; DNB TFT

Dogfael, holy man (fl. 6th cent.): T. M. Charles-Edwards, xvi.451; DNB TFT

Dyfrig, holy man and supposed bishop (supp. fl. c. 475-c. 525): David E. Thornton, xvii.494-5; DNB TFT

Faustus, bishop of Riez and theologian (400x10-c. 490): Clare Stancliffe, xix.161-3

Germanus, bishop of Auxerre (d. c. 437/48): Jill Harries, xx.965-6; DNB WH

Gildas, author ( $f$. 5th-6th cent.): François Kerlouégan, xxii.223-5; DNB TFT

Illtud, abbot of Llantwit Major (fl. 5th-6th cent.): David E. Thornton, xxix.208-9; $D N B$ DLT

Ninian, missionary and bishop (supp. fl. 5th-6th cent.): Dauvit Broun, xl.919; DNB James Mackinnon

*Non, mother of St David (fl. 6th cent.): J. Wyn Evans, xv.279; DNB JEL

Maglorius, ascetic ( $f$. late 6th cent.): Julia M. H. Smith, xxxvi.127-8; DNB MB

Mawgan, holy man (fl. 5th-6th cent.): Dauvit Broun, xxxvii.479-80; DNB MB

Padarn, founder of churches ( $f$. 6th cent.): Nerys Ann Jones, xlii.315; DNB JEL

Paul, bishop of St Pol-de-Léon, Brittany ( $f$. 6th cent.): Caroline Brett, xliii.126-7; DNB MB

Pelagius, theologian (fl. c. 390-418): Gerald Bonner, xliii.455-7; DNB C. R. Beazley

Petroc, monk ( $f$. 6th cent.): Caroline Brett, xliii.927; DNB JEL

Peulan, holy man ( $f$. 6th cent.): David E. Thornton, xliii.966-7; DNB JEL

Piran, holy man (supp. $f$ l. 6th cent.): Caroline Brett, xliv.402-3; DNB CLK

Samson, bishop (fl. 561/2): Julia M. H. Smith, xlviii.807-8; DNB JEL

Seiriol, holy man (fl. 6th cent.): David E. Thornton, xlix.686; DNB JEL

Teilo, holy man and bishop (supp. fl. c. 550): David E. Thornton, liv.28-9; DNB JEL

Tysilio, holy man (fl. c. 600): David E. Thornton, lv.817; DNB JEL

*Ursula, martyr ( $f$. mid-5th cent.): Richard W. Pfaff, lv.958-9; DNB Mary Tout

\section{c. Secular men and women}

Alypius, Roman official (fl. 360-c. 371): see Roman officials

Ambrosius Aurelianus, military leader ( $f$. 5 th cent.): David E. Thornton, i.922; DNB Arthur Miller

Aneirin, poet (fl. c. 575-c. 600): Morfydd Owen, ii.141-2; DNB Arthur Miller

Dyfnwal Moelmud ap Garbanion, dynast (fl. c. 450-70): Robin Chapman Stacey, xvii.493-4; DNB JEL

Gerontius, Roman general (d. 411): R. S. O. Tomlin, xxi.967-8

Merlin, poet and seer (supp. fl. 6th cent.): M. E. Haycock, xxxvii.898-9; DNB CLK Mordaf Hael, dynast (fl. c. 550-c. 575): David E. Thornton, xxxix.11-12; DNB JEL Pabo, chieftain (supp. fl. c. 500): Nerys Ann Jones, xlii.295-6; DNB JEL 


\section{Helen Foxhall Forbes et al.}

Roman officials (act. AD 43-410): A. R. Birley, xlvii.652-6

Taliesin, poet (fl. 6th cent.): T. M. Charles-Edwards, liii.737-8; DNB JEL

Victorinus, administrator (fl. 400): see Roman officials

\section{4. 'WELSH' SUBJECTS (c. 600-c. 1100)}

\section{a. Kings, consorts and other rulers}

Anarawd ap Rhodri, king in Wales (d. 916): rev. David E. Thornton, ii.12-13; DNB Arthur Miller

Bleddyn ap Cynfyn, king of Gwynedd and of Powys (d. 1075): Huw Pryce, vi.198-9

Cadell ab Arthfael, king of Gwent (d. 942): David E. Thornton, ix.401; DNB TFT

Cadell ap Rhodri, king in Wales (d. 910): David E. Thornton, ix.401-2; DNB TFT

Cadwaladr ap Cadwallon, king of Gwynedd (d. 664/82): David E. Thornton, ix.423-4; DNB TFT

Cadwallon ap Cadfan, king of Gwynedd (d. 634): T. M. Charles-Edwards, ix.425-6; $D N B$ W. R. W. Stephens

Cadfan ab Iago, king of Gwynedd (fl. c. 616-c. 625): David E. Thornton, ix.408; DNBTFT

Caradog ap Gruffudd ap Rhydderch, king in Wales (d. 1081): David Walker, x.10-11; $D N B$ TFT

Caradog ap Rhydderch, king in Wales (d. 1035): David Walker, x.10-11; DNB TFT

Cynan Garwyn, king of Powys (fl. c. 550-c. 600): David E. Thornton, xiv.858

Cynddylan ap Cyndrwyn, king in Wales (fl. c. 616-c. 641): David E. Thornton, xiv.859-60

Cyngen ap Cadell, king of Powys (d. 854/5): David E. Thornton, xiv.865-6

Gruffudd ap Cynan, king of Gwynedd (1054/5-1137): Huw Pryce, xxiv.133-5; DNB TFT

Gruffudd ap Llywelyn, king of Gwynedd and of Deheubarth (d. 1063): David Walker, xxiv.136-7; DNB TFT

Gruffudd ap Rhydderch, king in Wales (d. 1055): David Walker, x.10; DNB TFT

Gwynllyw, king of Glywysing (fl. 6th cent.): T. M. Charles-Edwards, xxiv.360-1; DNB TFT

Hywel [called Hywel Fychan], king of Gwynedd (d. 825): David E. Thornton, xxix.171-2; DNB TFT

Hywel ab Edwin, king of Deheubarth (d. 1044): rev. David E. Thornton, xxix.172; DNB TFT

Hywel ab Ieuaf, king of Gwynedd (d. 985): David E. Thornton, xxix.172-3; DNB TFT Hywel Dda, king in Wales (d. 950): David E. Thornton, xxix.175-6; DNB TFT Iago ab Idwal ap Meurig, king of Gwynedd (d. 1039): Huw Pryce, xxiv.133; DNB DLT Iago ab Idwal Foel, king of Gwynedd (d. c. 979): David E. Thornton, xxix.177; DNB DLT

Idwal ap Meurig, dynast (d. 996/7): David E. Thornton, xxix.190; DNB DLT Idwal Foel, king of Gwynedd (d. 942): David E. Thornton, xxix.190-1; DNB DLT 


\section{Anglo-Saxon and related entries in the ODNB (2004)}

Iorwerth ap Bleddyn, Welsh prince (d. 1111): Huw Pryce, vi.199; DNB TFT

Llywelyn ap Seisyll, king of Gwynedd and of Deheubarth (d. 1023): David Walker, xxiv.136; $D N B$ TFT

Maelgwn Gwynedd, king of Gwynedd (d. 547/49): David E. Thornton, xxxvi.100; $D N B$ JEL

Maredudd ab Owain, king of Gwynedd and of Deheubarth (d. 999): David E. Thornton, xxxvi.625-6; DNB JEL

Merfyn Frych, king of Gwynedd (d. 844): David E. Thornton, xxxvii.885-6; DNB JEL

Morgan ab Athrwys, king of Glywysing (d.c. 665/710): David E. Thornton, xxxix.945; $D N B$ JEL

Morgan Hen, king of Morgannwg (d. 974): David E. Thornton, xxxix.95-6; DNB JEL

Owain ab Edwin, ruler in Wales (d. 1105): David E. Thornton, xlii.176-7; DNB JEL

Owain ap Hywel, king of Deheubarth (b. before 929, d. 988): David E. Thornton, xlii. 177

Owain, Sir, ap Cadwgan, prince of Powys (d. 1116): Huw Pryce, vi.199; DNB JEL

Rhiwallon ap Cynfyn, king of Gwynedd and of Powys (d. 1069): Huw Pryce, vi.198-9; $D N B$ JEL

Rhodri Mawr, king of Gwynedd (b. before 844, d. 878): David E. Thornton, xlvi.611; $D N B$ JEL

Rhys ab Owain, ruler in Wales (d. 1078): rev. David E. Thornton, xlvi.614; DNB JEL

Rhys ap Tewdwr, ruler in Wales (d. 1093): rev. David E. Thornton, xlvi.619; DNB JEL

Selyf ap Cynan, king of Powys (d. 613x16): David E. Thornton, xlix.737-8

Trahaearn ap Caradog, ruler in Wales (d. 1081): rev. David E. Thornton, lv.203-4; DNB JEL

Urien Rheged, king of Rheged (fl. c. 560-c. 580): David E. Thornton, lv.944; DNB JEL

\section{b. Ecclesiastics}

Asser, bishop of Sherborne (d. 909): Patrick Wormald, ii.759-60; DNB [Anon]

Beulan, priest (fl. c. 1000-c. 1050): David E. Thornton, v.564-5; DNB WH

Beuno, holy man (d. 653/9): Patrick Sims-Williams, v.565-6; DNB Alexander Mackie

Bleddri, bishop in south-east Wales (d. 1022/3): rev. K. L. Maund, vi.198; DNB TFT

Cyfeilliog, bishop of Ergyng (d. 927): T. M. Charles-Edwards, xiv.857-8; DNB TFT

Elfoddw, archbishop of Gwynedd (d. 809): T. M. Charles-Edwards, xviii.31

Euddogwy, holy man (supp. fl. late 6th cent.): David E. Thornton, xviii.643; DNB JEL

Gudwal, bishop of St. Malo (supp. fl. 7th cent.): O. J. Padel, xxiv.165-6; DNB CLK

*Gulval, Cornish saint ( $f$ l. before 1000): O. J. Padel, xxiv.165-6; DNB CLK

*Gwenfrewi, nun (fl. c. 650): T. M. Charles-Edwards, xxiv.340-1; DNB MB

Herewald, bishop in south-east Wales and the border (d. 1104/7): K. L. Maund, xxvi.766-7; DNB TFT

Neot, monk and hermit (d. in or before 878): Michael Lapidge, xl.424; DNB MB

Rhigyfarch ap Sulien, scholar and teacher (1056/7-99): Michael Lapidge, xlvi.589-90; $D N B$ JEL

Sulien, bishop of St David's (c. 1012-91): rev. Nancy Edwards, liii.292; DNB JEL 


\section{Helen Foxhall Forbes et al.}

\section{c. Secular men and women}

Meilyr Brydydd, poet (fl. 1081-1137): rev. R. Geraint Gruffydd, xxxvii.726; DNB JEL Nennius, scholar (fl. c. 770-c. 810): David E. Thornton, xl.423-4; DNB CLK

\section{5. 'IRISH' SUBJECTS (c. 400-c. 1100)}

\section{a. Kings, consorts and other rulers}

Áed Allán mac Fergaile, high-king of Ireland (d. 743): T. M. Charles-Edwards, i.373 Áed mac Néill, high-king of Ireland (d. 879): Benjamin T. Hudson, i.373-4

Áed Oirdnide mac Néil, high-king of Ireland (d. 819): T. M. Charles-Edwards, i.374-5 Áed Sláine mac Diarmata, joint high-king of Ireland (d. 604): Philip Irwin, i.375-6

Áed [in Gaí Bernaig] Ua Conchobair, king of Connacht (d. 1067): Seán Duffy, lv.835-6; $D N B$ NM

Áed Uaridnach mac Domnaill, high-king of Ireland (d. 612): T. M. Charles-Edwards, i. 376

Ailill Molt, high-king of Ireland (d. c. 482): Philip Irwin, i.490

Báetán mac Cairill, king of Ulster (d. 581): Philip Irwin, iii.212

Blaímac [Blathmac] mac Áeda, joint high-king of Ireland (d. 665): T. M. CharlesEdwards, vi.70

Brian Bóruma, high-king of Ireland (c. 941-1014): Seán Duffy, vii.533-8; DNB NM

Cathal mac Conchobair, king of Connacht (d. 1010): Seán Duffy, x.536; DNB NM

Cathal mac Finguine, king of Munster (d. 742): Philip Irwin, x.536-7

Cellach mac Máele Coba, joint high-king of Ireland (d. 658): T. M. Charles-Edwards, x.805-6

Cellach Cualann, king of Leinster (d. 715): Charles Doherty, x.804-5

Cellachán mac Buadacháin, king of Munster (d. 954): Benjamin T. Hudson, x.806; $D N B$ NM

Cenn Fáelad mac Blaímaic, high-king of Ireland (d. 675): T. M. Charles-Edwards, x.810 Cerball mac Dúngaile, king of Osraige (d. 888): Benjamin T. Hudson, x.821-2; DNBNM Cináed mac Írgalaig, high-king of Ireland (d. 728): T. M. Charles-Edwards, xi.712-13

Coirpre mac Néill, high-king of Ireland (supp. fl. 485-94): Philip Irwin, xii.441

Conall Cóel mac Máele Coba, joint high-king of Ireland (d. 654): T. M. CharlesEdwards, x.805-6

Conchobar mac Donnchada, high-king of Ireland (d. 833): Benjamin T. Hudson (online update, October 2005)

Congal Cáech, high-king of Ireland (d. 637): T. M. Charles-Edwards, xii.929

Congal Cendmagair, high-king of Ireland (d. 710): Charles Doherty, xii.929-30

Congalach mac Máele Mithig, king of Brega and high-king of Ireland (d. 956): Benjamin T. Hudson, xii.930

Cormac mac Cuilennáin, king of Munster and bishop (d. 908): Paul Russell, xiii.434-5; $D N B$ NM

Dál Riata, kings of: see sect. $6 a$, 'Scottish' kings and other rulers 


\section{Anglo-Saxon and related entries in the ODNB (2004)}

Diarmait mac Cerbaill, high-king of Ireland (d. 565): T. M. Charles-Edwards, xvi.22-3 Diarmait mac Máel na mBó, king of Leinster (d. 1072): Benjamin T. Hudson, xvi.23

Domnall mac Áeda, high-king of Ireland (d. 642): T. M. Charles-Edwards, xvi.489-90

Domnall mac Murchada, high-king of Ireland (d. 763): T. M. Charles-Edwards, xvi.490 Domnall ua Néill, high-king of Ireland (d. 980): Benjamin T. Hudson, xvi.490-1

Donnchad Donn mac Flainn, high-king of Ireland (d. 944): Charles Doherty, xvi.532-3 Donnchad mac Briain, king of Munster (d. 1064): Damian Bracken, xxxv.65-7; DNB NM

Donnchad mac Domnaill, high-king of Ireland (733-97): Charles Doherty, xvi.533-4

Feidlimid mac Crimthainn, king of Munster (d. 847): Damian Bracken, xix.235-6

Fergal mac Máele Dúin, high-king of Ireland (d. 722): Charles Doherty, xix.338-9

Fiachu mac Néill, king in Ireland (fl. 510-16): Philip Irwin, xix.462

Fínsnechtae Fledach mac Dúnchada, high-king of Ireland (d. 695): T. M. CharlesEdwards, xix.629

Flaithbertach mac Loingsig, high-king of Ireland (d. 765): T. M. Charles-Edwards, xix.979

Flaithbertach ua Néill, king of Ailech (d. 1036): Seán Duffy, lv.844-5; DNB NM

Flann Sinna, high-king of Ireland (847/8-91): Charles Doherty, xix.998-9

Fogartach mac Néill, high-king of Ireland (d. 724): Philip Irwin, xix.199-200

Forggus mac Muirchertaig, joint high-king of Ireland (d. c. 566): T. M. CharlesEdwards, xix.366-7

Godred Crovan, king of Man and the Isles (d. 1095): Seán Duffy, xxii.600-1

*Gormlaith, queen in Ireland and tragic heroine (d. 948): Elva Johnston, xxii.1011

Lethlobar mac Loingsig, king of Ulster (d. 873): Benjamin T. Hudson, xxxiii.509-10; $D N B$ NM

Lóegaire mac Néill, high-king of Ireland ( $f$. 5th cent.): Philip Irwin, xxxiv.292-3; DNB $\mathrm{NM}$

Loingsech mac Óenguso, high-king of Ireland (d. 704): Máirín Ní Dhonnchadha, xxxiv.329; $D N B$ NM

Lugaid mac Lóegairi, high-king of Ireland (d. 507): Philip Irwin, xxxiv.724; DNB NM

Máel Sechnaill mac Domnaill, high-king of Ireland (948-1022): Benjamin T. Hudson, xxxvi.101-2; DNB NM

Máel Sechnaill mac Máele Ruanaid, high-king of Ireland (d. 862): T. M. CharlesEdwards, xxxvi.102-4; DNB NM

Muirchertach mac Muiredaig, high-king of Ireland (d. 534): T. M. Charles-Edwards, xxxix.681-2; DNB NM

Muirchertach mac Néill, king of Ailech (d. 943): Benjamin T. Hudson, xxxix.682-3; $D N B$ NM

Muirchertach ua Briain, high-king of Ireland (c. 1050-1119): Damian Bracken, lv.830-2; $D N B$ NM

Nath Í mac Fiachrach, high-king of Ireland (supp. d. 445?): Philip Irwin, xl.264

Niall Frossach mac Fergaile, high-king of Ireland (718-78): Philip Irwin, xl.743-4; $D N B \mathrm{NM}$ 


\section{Helen Foxhall Forbes et al.}

Niall [Caille] mac Áeda, king of Ailech and high-king of Ireland (d. 846): Benjamin T. Hudson, xl.744-5; DNB NM

Niall [Glúndub] mac Áeda, king of Ailech and high-king of Ireland (c. 869-919): Benjamin T. Hudson, xl.745; $D N B$ NM

Niall mac Eochada, king of Ulaid (d. 1063): Benjamin T. Hudson, xl.746; DNB NM

Niall mac Maíl Shechnaill, king of Ailech (d. 1061): T. M. Charles-Edwards, xl.746-7; $D N B$ NM

Níall Noígíallach, high-king of Ireland (d. c. 452): Fergus Kelly, xl.747-8; DNB NM

Nigel [= Niall Glúndub mac Áeda] (d. 919): Marios Costambeys, xl.900; DNB AMC

Óláf Guthfrithson, king of Dublin and of Northumbria (d. 941): Benjamin T. Hudson, xli.662-3; DNB AMC

Óláf Sihtricson, king of Dublin and of Northumbria (c. 926-81): Benjamin T. Hudson, xli.663-5; DNB AMC

Ragnall Guthfrithson, viking king (fl. 943-4): Marios Costambeys, xlv.796-7; DNB AMC Ruaidrí ua Canannáin, king of Cenél Conaill (d. 950): Charles Doherty, xlviii.62-3

Ruaidrí [na Saide Buide] ua Conchobair, king of Connacht (d. 1118): Seán Duffy, lv.836; DNB NM

Sechnassach mac Blathmaic, high-king of Ireland (d. 671): Philip Irwin, xlix.621

Sihtric, king of Dublin (d. 1042): Benjamin T. Hudson, 1.596-7; DNB F. Y. Powell

Suibne Menn mac Fiachnai, high-king of Ireland (d. 628): T. M. Charles-Edwards, liii. 290

Toirdelbach ua Briain, king of Munster (1009-86): Damian Bracken, lv.832-3; DNB NM

Tuathal Máelgarb mac Cormaic, high-king of Ireland ( $f$. 535-9): T. M. CharlesEdwards, lv.484-5; DNB NM

\section{b. Ecclesiastics}

Adomnán, abbot of Iona and writer (627/8?-704): Máirín Ní Dhonnchadha, i.353-6; $D N B$ J. T. Gilbert

Áed mac Bricc, bishop of Rahugh, Killare and Slieve League; saint of Cenél Fiachach (d. 589): see Meath, saints of

Áedán, missionary and bishop (d. 651): Henry Mayr-Harting, i.376-7; DNB Mandell Creighton

Ailbe, bishop, church founder, saint of Munster (d. 534?): see Munster, saints of

Ailerán, scholar (d. 665): Thomas O’Loughlin, i.489-90

Airbertach mac Cosse Dobráin, poet (d. 1016): Peter J. Smith, i.511-12

Assicus, holy man (fl. c. 480): see Ulster, saints of

*Athracht ingen Thaláin, holy woman (fl. c. 500): see Connacht, saints of

Béoáed mac Ocláin, bishop (d. (520/24): see Connacht, saints of

Berach mac Amargin, holy man ( $f$. late 6th-early 7 th cent.): see Connacht, saints of

Brendan mac Nemainn, holy man (d. (565/73): see Meath, saints of

Brendan of Clonfert, holy man (d. 577): see Connacht, saints of

*Brigit, patron saint of Kildare (439/52-524/6): T. M. Charles-Edwards, vii.650-4; $D N B$ TO 


\section{Anglo-Saxon and related entries in the ODNB (2004)}

Brón mac Icni, holy man (d. 512): see Connacht, saints of

*Brónach, holy woman ( $f$. 5th-6th cent.?): see Ulster, saints of

Buíte mac Brónaig, holy man (d. 519/20): see Meath, saints of

Caillín mac Niataig, holy man ( $f$. 6th cent.): see Meath, saints of

Caimín, holy man (d. 644): see Munster, saints of

Cainnech moccu Dálann, holy man (521/7-599/600): see Munster, saints of

*Cairech Dergain, holy woman (d. 577/9): see Connacht, saints of

Cairnech, holy man ( $f$. 5th-early 6th cent.): see Meath, saints of

Camulacus, holy man ( $f$. 5th cent.?): see Meath, saints of

*Canir, saint ( $f$. 6th cent.): see Munster, saints of

Carthach mac Fianáin, holy man ( $f$. late 6th cent.): see Munster, saints of

Catroe, abbot of St Felix, Metz (900/1-971): Alan Macquarrie, x.559-60; DNB T. A. Archer

Cellach, bishop of Killala ( $f$. 6th-7th cent.): Paul Russell, x.803; DNB TO

Cellán, abbot of Péronne and writer (d. 706): Michael Lapidge, x.806-7

Céthech, bishop ( $f$. 5 th cent.): see Connacht, saints of

Cianán mac Sétnai, saint (d. 489): see Meath, saints of

Ciarán mac int Shaír, saint (c. 515-584/9): see Meath, saints of

Ciarán mac Luaigne, bishop and patron of Ossory (fl. 450-500): see Munster, saints of; $D N B$ TO

Clement, alleged heretic (fl. 744-7): Timothy Reuter, xii.18-19; DNB R. L. Poole

Cóemgen, founder of Glenn Dá Locha ( $f$. 7 th cent.): see Leinster, saints of; $D N B$ TO

Coirpre Crom mac Feradaig, bishop of Clonmacnoise (d. 904): see Meath, saints of; $D N B$ TO

Colcu ua Duinechda, scriba, and probably bishop of Clonmacnoise (d. 796): see Meath, saints of; $D N B$ TO

Colmán, bishop of Lindisfarne (d. 676): Marios Costambeys, xii.756-7; DNB WH

Colmán Elo, saint (d. 611): see Meath, saints of; DNB TO

Colmán mac Léníne, saint (530-606): see Munster, saints of

Colum mac Crimthainn, monastic founder (d.548): see Munster, saints of

Columbanus, missionary and monastic founder (d. 615): Rob Meens, xii.810-13; DNB WH

Comgall mac Sétnai, monastic founder (511/16-602): see Ulster, saints of; DNB T. A. Archer

Comgán mac Dá Cherda, possible abbot of Emly (d. 645): see Munster, saints of

Commán mac Fáelchon, patron of Roscommon (d. 747): see Connacht, saints of; DNB TO

Conlaíd, patron of Kildare (d. 518/520): T. M. Charles-Edwards, vii.650; DNB TO

Conn na mBocht, ecclesiastical leader (d. 1060): Seán Duffy, xii.957-8; DNB TO

Connacht, saints of, holy men and women believed to have been buried within the province of Connacht (act. c. 400-c. 800): T. M. Charles-Edwards, xii.960-3

Cormac mac Eogain, saint in Connacht (fl. 6th cent.): see Connacht, saints of; DNB TO

Cormac ua Liatháin, monastic founder and navigator ( $f$. late 6th cent.): see Meath, saints of 


\section{Helen Foxhall Forbes et al.}

*Cranat ingen Buicín, saint ( $f$. 6th cent.): see Munster, saints of

Crónán moccu Éile, monastic founder (d. 665): see Munster, saints of; DNB T. A. Archer

Cumméne Fota, bishop of Clonfert and Ardfert (c. 591-662): see Connacht, saints of Daig mac Cairill, saint of Ulster (d. 587): see Ulster, saints of

*Dar Lugdach, abbess of Kildare (d. 525/7): T. M. Charles-Edwards, xv.105; DNB TO

Déclán mac Eircc, saint of Munster ( $f$. late 5th cent.): see Munster, saints of; DNB TO

Decuman, holy man (fl. 6th cent.): David E. Thornton, xv.663-4; DNB WH

Deicolus, Benedictine monk and hermit (d. c. 625): Dagmar Ó Riain-Raedel, xv.695; $D N B$ TO

*Dergain, saint (d. 577-9): T. M. Charles-Edwards, xxii.963

Díchu mac Trichim, saint ( $f$. 5th cent.): see Ulster, saints of

Disibod, holy man (supp. d. 674): Marios Costambeys, xvi.264; DNB TO

Do Biu mac Comgaill, saint (fl. 5th cent.?): see Ulster, saints of

Donatus, bishop of Fiesole (d. 876): Paul Russell, xvi.520-1; DNB TO

Donngus Ua hAingliu, bishop of Dublin (d. 1095): M. T. Flanagan, lv.842-3; DNB TO

Dub dá Leithe, abbot of Armagh (d. 1064): Benjamin T. Hudson, xvii.9-10; DNB TO

Dublitter, saint of Meath (d. 796): see Meath, saints of

Dúnán, bishop of Dublin (d. 1074): Benjamin T. Hudson, xvii.199-200; DNB TO

Dúngal, astronomer and theologian (fl. c. 800-27): David Ganz, xvii.297-8; DNB TO

*Dympna, martyr ( $f$ l late 6th-early 7th cent.): Nathalie Stalmans, xvii.505-6; DNB TO

Énda mac Conaill, saint of Munster ( $f$. 6th cent.?): see Munster, saints of; DNB TO

Eochaid ua Flannucáin, poet and historian (c. 936-1004): John Carey, xviii.472-3

Erc mac Dega, saint of Meath (d. 513): see Meath, saints of

*Ercnat ingen Dáire, saint of Ulster ( $f$. 5th-6th cent.): see Ulster, saints of

Éogan mac Dega, saint of Ulster ( $f$. late 6th cent.): see Ulster, saints of

Erhard, bishop of Regensburg (d. before 784): Marios Costambeys, xviii.496-7; DNB TO

Fachtna mac Mongaig, saint of Munster ( $f$. 6th cent.): see Munster, saints of; $D N B$ TO

Féchín moccu Cháe, saint of Meath (d. 665): see Meath, saints of; DNB NM

Fiachra, monastic founder ( $f$. mid-7th cent.): Elva Johnston, xix.461-2; DNB TO

Finán, missionary and bishop of Lindisfarne (d. 661): R. Jayatilaka, xix.549-50

Fínán Cam mac Móenaig, saint of Meath ( $f$. late 6th-early 7th cent.): see Meath, saints of

Findbarr mac Amairgin, saint of Munster ( $f$. 6th cent.?): see Munster, saints of

Findbarr moccu Fiatach, saint of Ulster (d. 579): see Ulster, saints of

Findchú mac Finnloga, saint of Munster (d. 655/65): see Munster, saints of; DNB TO

Finnián mac Findloga, saint of Meath (d. 549/51): see Meath, saints of; DNB TO

Fintan, saint of Leinster (d. 603?): see Leinster, saints of; $D N B$ TO

Finten, saint of Leinster ( $f$. 7 th cent.): see Leinster, saints of; $D N B$ TO

Flann mac Lonáin, poet (d. 891x918): Peter J. Smith, xix.996-7; DNB NM

Flann Mainistrech, poet and historian (d. 1056): John Carey, xix.997-8; DNB NM 


\section{Anglo-Saxon and related entries in the ODNB (2004)}

Flannán mac Toirrdelbaig, saint of Munster ( $f$. 7 th cent.): see Munster, saints of; $D N B$ TO

Foillan, holy man (d. 653x5): Fouracre, Paul, xix.203-4; DNB TO

Forannán, bishop of Donaghmore and abbot of Waulsort (d. 982): Nathalie Stalmans, xix.253-4; $D N B$ TO

*Funech, saint of Meath ( $f$. late 7 th cent.): see Meath, saints of

Fursa, missionary monk (d. 649): Paul Fouracre, xx.201-2; DNB TO

Gall, supposed monastic founder ( $f$. 615): Dagmar Ó Riain-Raedel, xx.307-8; DNB WH

Garald, saint of Connacht (d. 732): see Connacht, saints of; DNB TO

Gobbán Sáer, legendary Irish church-builder (supp. fl. 7th. cent.): Elva Johnston, xxxviii.469; DNB TO

*Gobnait, Irish saint ( $f$. 6th cent.?): see Munster, saints of

Grellán of Cráeb Grelláin, Irish saint ( $f$. 5th-6th cent.): see Connacht, saints of; $D N B$ TO

Guasacht maccu Buáin, bishop of Granard (Meath): ( $f$. late 5th cent.): see Meath, saints of

Iarlaithe, supposed bishop of Armagh (supp. d. 481): T. M. Charles-Edwards, xxix.17980; $D N B$ NM

Iarlaithe mac Loga, Irish saint (fl. 6th cent.): see Connacht, saints of; $D N B$ NM

Ibar mac Lugna, Irish bishop (d. 500/1): see Munster, saints of; DNB W. A. J. Archbold

Iona, abbots of: see section 6b, 'Scottish' ecclesiastics

*Íte ingen Chinn Fhalad, Irish saint (d. 570/7): see Munster, saints of; DNB NM

John Scottus [called John Scottus Eriugena], theologian (fl. c. 845-c. 870): John Marenbon, xxx.196-203; DNB R. L. Poole

Joseph Scottus, abbot and scholar (d. 791x804): Mary Garrison, xxx.715-16

*Kentigerna, anchorite (d. 734): Henrietta Leyser, xxxi.334

Killian, missionary in Franconia (d. 689?): Dagmar Ó Riain-Raedel, xxxi.548-9; DNB NM

Lachtín mac Tarbín, saint (d. 622/7): see Munster, saints of; DNB NM

Laisrén mac Decláin, saint (fl. 6th cent.): see Connacht, saints of

*Lallóc, saint ( $f$. 5th cent.): see Connacht, saints of

Leinster, saints of (act. c. 550-c. 800): Charles Doherty, xxxiii.277-9

Livinus, missionary (supp. d. 633?): David E. Thornton, xxxiv.88-9; DNB MB

Lommán mac Dalláin, saint ( $f$. 5th-early 6th cent): see Meath, saints of

Lonán mac Talmaig, saint ( $f$. 5th-6th cent.): see Meath, saints of

Mac Caírthinn mac Cainnig, saint (d. 506): see Ulster, saints of

Mac Creiche mac Pessláin, saint ( $f$. late 6th cent.): see Munster, saints of

Mac Cuilinn mac Cathmoga, saint (d. 496): see Meath, saints of

Mac Nisse mac Faíbrig, saint (d. 507/8): see Ulster, saints of

Máedóc, saint ( $f$. 7 th cent.): see Leinster, saints of

Máel Cétair mac Rónáin, saint ( $f$ l. 6th-7th cent.?): see Munster, saints of

Máel Muru Othna, poet and historian (d. 887): John Carey, xxxvi.100-1; DNB NM 


\section{Helen Foxhall Forbes et al.}

Máel Ruain, saint (d. 792): see Leinster, saints of

Máel Suthain Ua Cerbaill, ecclesiastic (d. 1010): T. M. Charles-Edwards, lv.835; DNB NM

Máeldub, abbot (supp. fl. mid-7th cent.): Michael Lapidge, xxxvi.99-100; DNB MB

Mainchín mac Setnai, saint ( $f$. late 6th cent.): see Munster, saints of

Manchán mac Silláin, saint (d. 665): see Meath, saints of

Marianus Scotus, Benedictine monk and chronicler (1028-82): rev. P. McGurk, xxxvi.665-6; DNB CLK

Martin of Laon, scholar (819-75): John J. Contreni, xxxvi.917-18

Meath, saints of (c. 400-c. 900): Nathalie Stalmans; T. M. Charles-Edwards, xxxvii.671-8

Mél, saint ( $f$. 5th-early 6th cent.): see Meath, saints of; $D N B \mathrm{NM}$

Mo Chóe mac Luacháin, saint (d. 497): see Ulster, saints of; DNB TO

Mo Chóemóc mac Béoáin, founder of Leamakevoge (d. 656): see Munster, saints of; $D N B$ TO

Mo Chua mac Bécáin, saint (d. 694): see Connacht, saints of; DNB TO

Mo Chutu mac Fínaill, abbot of Rahan (Rathan) and abbot-founder of Lismore (Les Mór Mo Chutu) (d. 637): see Munster, saints of; DNB T. A. Archer

Mo Genóc, saint ( $f$. 5 th cent.?): see Meath, saints of

Mo Laga mac Duib Dligid, saint ( $f$. late 6th cent.?): see Munster, saints of; DNB TO

Mo Laisse mac Nad Froích, saint (d. 564): see Ulster, saints of; $D N B$ NM

Mo Ling, abbot of St Mullins (d. 697): Elva Johnston, xxxviii.469-70; DNB TO

Mo Lua moccu Óche, saint (554-609): see Munster, saints of; DNB MB

Mochtae, saint (d. 535): see Meath, saints of

Modestus, missionary (d. c. 763): Luned Mair Davies, xxxviii.486; DNB MB

Móenu, bishop of Clonfert, saint (d. 572): see Connacht, saints of; DNB MB

*Moninne, nun (d. 517): Robert Bartlett, xxxviii.625; DNB TO

Mucnoe, saint (fl. c. 500): see Connacht, saints of

Muirchú, biographer (fl. 697): David E. Thornton, xxxix.683; DNB TO

Muiredach mac Echdach, saint ( $f$. early 6th cent.): see Connacht, saints of

Munis, bishop ( $f$. 5th cent.?): see Meath, saints of

Munster, saints of (act. c. 450-c. 750): Elva Johnston, xxxix.783-93

Muru mac Feradaig, saint of Ulster (c. 600-c. 650): see Ulster, saints of; DNB NM

Nessán, saint of Munster (d. 556): see Munster, saints of

Óengus of Tallaght, bishop and writer (fl. c. 830): Pádraig Ó Riain, xli.540-1

Olcán, saint of Ulster ( $f$. 5th cent.): see Ulster, saints of

Palladius, missionary and bishop (fl. 429-c. 433): T. M. Charles-Edwards, xlii.461-2;

$D N B$ C. R. Beazley

Patrick, patron saint of Ireland (fl. 5th cent.): Clare Stancliffe, xliii.69-80; DNB TO

Plechelm, missionary and bishop ( $f$. 8th cent.): Nathalie Stalmans, xliv.574; $D N B$ MB

Probus, writer (fl. 9thx11th cent.): David E. Thornton, xlv.447-8; DNB TO

Ruadán mac Fergusa Birn, saint of Munster (d. 584): see Munster, saints of

Rumold, martyr ( $f$. 7th-8th cent.): Nathalie Stalmans, xlviii.115-16; DNB TO

Sachellus, saint of Connacht ( $f$. 5th cent.): see Connacht, saints of 


\section{Anglo-Saxon and related entries in the ODNB (2004)}

*Samthann ingen Díaráin, saint of Meath (d. 739): see Meath, saints of Sechnall mac Restitiúit, saint of Meath ( $f$. 5th cent.): see Meath, saints of Sedulius, religious writer ( $f$. 7th-8th cent.): Clare Stanfcliffe, xlix.659-60; DNB TO Sedulius Scottus, poet and scholar (fl. 840x51-860x74): Luned Mair Davies, xlix.660-1 Senán mac Geirrcinn, saint of Munster ( $f$. 6th cent.): see Munster, saints of; $D N B$ TO Sillán moccu Mind, saint of Ulster (d. 610): see Ulster, saints of Tigernach mac Coirpri, saint (d. 549): see Ulster, saints of

Tigernach Ua Briaín, abbot of Clonmacnoise (d. 1088): T. M. Charles-Edwards, lv.889; $D N B$ NM

Tírechán, bishop and hagiographer (fl. c. 690): David E. Thornton, liv.836-7; DNB TO Ulster, saints of (act. c. 400-c. 600): T. M. Charles-Edwards, lv.872-8

Ultán moccu Chonchobair, saint (d. 657): see Meath, saints of; $D N B$ NM

Virgilius, bishop of Salzburg (d. 784): Dagmar Ó Riain-Raedel, lvi.561-2; DNB TO

\section{c. Secular men and women}

Arnórr Earls' Poet, court poet in Iceland (fl. c. 1046-73): Paul Bibire, ii.511

Barinthus, legendary navigator (supp. fl. 6th cent.): David E. Thornton, iii.857; DNB T. A. Archer

Cináed ua hArtacáin, poet (d. 975): John Carey, xi.713; DNB NM

Clemens Scotus, grammarian (fl. c. 814-26): V. A. Law, xii.17-8; DNB R. L. Poole

Cuán ua Lothcháin, Gaelic poet (d. 1024): John Carey, xiv.574-5; DNB NM

Dallán Forgaill, poet (fl. 597): T. M. Charles-Edwards, xiv.954-5; DNB NM

Dícuil, scholar and teacher (fl. c. 795-825): John J. Contreni, xvi.132-4; DNB T. A. Archer.

Dubthach maccu Lugair, poet (supp. fl. 432): T. M. Charles-Edwards, xvii.22-3; DNB TO

Gilla Coémáin, Gaelic poet (fl. 1072): Peter J. Smith, xxii.253

Ívarr [Ívarr inn Beinlausi], viking leader (d. 873): Marios Costambeys, xxix.443-5

Muirchertach, poet (d. 1014/16): Peter J. Smith, xxxix.681; DNB NM

Oisín, legendary hero (supp. $f$ l. 3rd-5th cent.): Máirtín Ó Briain, xli.645; DNB [Anon]

Óláf the White, viking leader (fl. 853-71): Benjamin T. Hudson, xli.665

Ruben mac Connad, scribe (d. 725): Luned Mair Davies, xlviii.66

Senchán Torpéist, Gaelic poet (fl. 6th-7th cent.): Elva Johnston, xlix.753-4; DNB NM Sihtric Cam, warrior (fl. 962): Benjamin T. Hudson, xli.663-5; DNB F. Y. Powell Turges, viking leader (d. 845): Benjamin T. Hudson, lv.576; DNB AMC Urard mac Coise, Gaelic poet (d. 983x1023): Elva Johnston, lv.936; DNB TO

\section{6. 'SCOTTISH' SUBJECTS (c. 400-c. 1100)}

\section{a. Kings, consorts and other rulers}

Adda, king of Bernicia (d. 565?): D. J. Craig, xxix.189; DNB WH

Aed Find, king of Dál Riata (d. 778): see Dál Riata, kings of 


\section{Helen Foxhall Forbes et al.}

Aedán mac Gabrán, king of Dál Riata (c. 535-609?): Marjorie Anderson, i.378; DNB [Anon]

Ainfcellach, king of Dál Riata (d. 719): see Dál Riata, kings of

Alchfrith, sub-king of Deira (fl. c. 655- c. 665): Rosemary Cramp, i.589; DNB WH

Alpin, king of Dál Riata (d. 840): see Dál Riata, kings of

Brude [Bridei] mac Bile, king of Picts (d. 693): Marjorie O. Anderson, viii.342-3

Brude [Bridei] mac Maelchon, king of Picts (d.c. 586): Marjorie O. Anderson, viii.343

Comgall mac Domangart, king of Dál Riata (d. c. 538): see Dál Riata, kings of; $D N B$ AJGM

Conall Crandomna, king of Dál Riata (d. 660): see Dál Riata, kings of; DNB AJGM

Conall mac Comgall, king of Dál Riata (d. 574): see Dál Riata, kings of; DNB AJGM

Connad Cerr, king of Dál Riata (d. c. 629): see Dál Riata, kings of

Constantine I, king in Scotland (d. 876): Dauvit Broun, xiii.32; DNB AJGM

Constantine II, king in Scotland (d. 952): Dauvit Broun, xiii.32-3; DNB AJGM

Constantine III, king in Scotland (d. 997): Dauvit Broun, xiv.572-3; DNB AJGM

Constantine mac Fergus, king of the Picts (d. 820): see Picts, kings of the; DNB AJGM

Culen, king in Scotland (d. 971): Dauvit Broun, xiv.572-3; DNB AJGM

Dál Riata, kings of (act. c. 500-c. 850): Marjorie O. Anderson, xiv.971-8

Domangart, king of Dál Riata (d. 673): see Dál Riata, kings of

Domnall Brecc, king of Dál Riata (d. 642/3): Marjorie O. Anderson, xvi.489; DNB AJGM

Donald [Dyfnwal son of Owen], king of the Cumbrians (d. 975): Alan Macquarrie, xvi.494

Donald I [Domnall mac Alpin], king in Scotland (d. 862): Marjorie O. Anderson, xvi.496; DNB AJGM

Donald II, king in Scotland (d. 900): Dauvit Broun, xvi.496; DNB AJGM

Donald III, king of Scots (b. in or before 1040, d. 1099?): A. A. M. Duncan, xvi.496-7

Drust, king of the Picts (d. 729): see Picts, kings of the

Drust, king of the Picts (d. c. 848): see Picts, kings of the

Dubh, king in Scotland (d. 966): Dauvit Broun, xvii.11-12; DNB AJGM

Duncan I, king of Scots (d. 1040): Dauvit Broun, xvii.218-19; DNB T. A. Archer

Dúngal, king of Dál Riata (d. c. 736): see Dál Riata, kings of

Eochaid, ruler in Scotland (d. 697): see Dál Riata, kings of; DNB AJGM

Eochaid Buide, ruler in Scotland (d. c. 629): see Dál Riata, kings of; DNB AJGM

Eoganán, king of the Picts (d. 839): see Picts, kings of the

Eugenius I-VIII, Scottish kings (act.c. 350-763): Henry Summerson, xviii.644-5; DNB AJGM

Ewen [Eogan], ruler in Scotland (d. 763): see Dál Riata, kings of

Ferchar, ruler in Scotland (d. c. 651): see Dál Riata, kings of; DNB AJGM

Ferchar Fota, ruler in Scotland (d. 697): see Dál Riata, kings of; DNB AJGM

Fergus, ruler in Scotland (d. 501): see Dál Riata, kings of; DNB AJGM

Fiannamail, ruler in Scotland (d. 700): see Dál Riata, kings of

Gabrán, ruler in Scotland (d. c. 558): see Dál Riata, kings of

Giric mac Dúngal, king in Scotland (d. c. 890): Dauvit Broun, xxii.347; DNB AJGM 


\section{Anglo-Saxon and related entries in the ODNB (2004)}

Ida, king of Bernicia (d. 559/60): D. J. Craig, xxix.188-9; DNB WH

Indulf, king in Scotland (bap. 927?, d. 962): Dauvit Broun, xxix.230; DNB AJGM

Kenneth I [Cináed mac Alpin], king in Scotland (d. 858): Marjorie O. Anderson, xxxi.278-9; DNB AJGM

Kenneth II, king in Scotland (d. 995): Dauvit Broun, xxxi.279-80; DNB AJGM

Kenneth III, king in Scotland (d. 1005): Dauvit Broun, xxxi.280; DNB AJGM

Lulach, king of Scots (d. 1058): Dauvit Broun, xxxv.60; DNB WH

Macbeth, king of Scots (d. 1057): Dauvit Broun, xxxv.59-60; DNB AJGM

Malcolm I, king in Scotland (d. 954): Dauvit Broun, xxxvi.278-9; DNB AJGM

Malcolm II, king of Scots (d. 1034): Dauvit Broun, xxxvi.279; DNB AJGM

Malcolm III, king of Scots (d. 1093): G. W. S. Barrow, xxxvi.279-81; DNB AJGM

*Margaret, queen of Scots, consort of Malcolm III (d. 1093): G. W. S. Barrow, xxxvi.632-3; DNB AJGM

Muredach, ruler in Scotland (d. 771): see Dál Riata, kings of

Nechtan mac Derile, king of Picts (d. 732): Marjorie O. Anderson, xl.313; DNB AJGM

Nechtan Morbet, king of Picts (d. 481?): see Picts, kings of the; DNB AJGM

Oengus, king of Picts (d. 834): see Picts, kings of the

Oengus mac Forgusso [Onuist son of Uurguist], king of Picts (d. 761): Marjorie O.

Anderson, xli.540

Owen the Bald, king of the Cumbrians (d. 1018): Alan Macquarrie, xvi.494

Picts, kings of the (act.c. 300-c. 900): Marjorie O. Anderson, xliv.243-6

Selbach, king of Dál Riata (d. 730): see Dál Riata, kings of; DNB AJGM

Talorg mac Congus, king of the Picts (d.734): see Picts, kings of the

Talorgan mac Drostan, king of the Picts $(d .739)$ : see Picts, kings of the

Talorgen, king of the Picts (d. 657): see Picts, kings of the

\section{b. Ecclesiastics}

Baithéne mac Brénainn, abbot of Iona (d. 598): see Iona, abbots of

Beoán, bishop of Mortlach (supp. fl. 1012x24): Elva Johnston, v.314; DNB [Anon]

Blaímac [Blathmac] mac Flainn, abbot of Iona (d. 825): see Iona, abbots of

Bresal mac Ségéni, abbot of Iona (d. 801): see Iona, abbots of

Cellach mac Ailella, abbot of Iona (d. 815): see Iona, abbots of

Cellach mac Congaile, abbot of Iona (d. 815): see Iona, abbots of

Cilléne Droichtech, abbot of Iona (d. 752): see Iona, abbots of

Cilléne Fota, abbot of Iona ( $d$. 726): see Iona, abbots of

Columba, monastic founder (c. 512-597): Máire Herbert, xii.805-10; DNB NM

Conamail mac Faílbi, abbot of Iona (d. 710): see Iona, abbots of

Connachtach, abbot of Iona (d. 802): see Iona, abbots of

Cú Chuimne, canonist and hymn writer (d. 747): Luned Mair Davies, xiv.574

Cumméne Albus, abbot of Iona (d. 669): see Iona, abbots of; DNB TO

Diarmait alumnus Daigri, abbot of Iona (d. in or after 831): see Iona, abbots of

Donnán, martyr (d. 617): Marios Costambeys, xvi.531-2

Dorbéne mac Altaíni, abbot of Iona (d. 713): see Iona, abbots of

Dúnchad mac Cind Fháelad, abbot of Iona (d. 717): see Iona, abbots of 


\section{Helen Foxhall Forbes et al.}

Fáelán, abbot of Iona (fl. 734): rev. Benjamin T. Hudson, xviii.886; DNB W. D. Macray Fáelán Amlabar, abbot of Iona (641/2-724): rev. Benjamin T. Hudson, xviii.886; DNB W. D. Macray

Fáelchú mac Dorbéni, abbot of Iona (d. 724): see Iona, abbots of Faílbe mac Pípáin, abbot of Iona (d. 679): see Iona, abbots of

Feradach mac Cormaic, abbot of Iona (d. 880): see Iona, abbots of Flann mac Maíle Dúin, abbot of Iona (d. 891): see Iona, abbots of Innrechtach ua Finnachtai, abbot of Iona (d. 854): see Iona, abbots of Iona, abbots of (act. 563-927) [group entry]: T. M. Charles-Edwards, xxix.316-21

Kentigern, patron of the diocese (later archdiocese) of Glasgow (d. 612x14): Dauvit Broun, xxxi.333-4; DNB G. W. Sprott

Laisrén mac Feradaig, abbot of Iona (d. 605): see Iona, abbots of

Máel Brigte mac Tornáin, abbot of Iona (d. 927): see Iona, abbots of

Mo Nennus, ascetic and teacher ( $f$. 5th-early 6th cent.): Elva Johnston, xxxviii.470-1; $D N B \mathrm{MB}$

Monan, supposed holy man (fl. 6th-7th cent.): Alan Macquarrie, xxxviii.574-5; $D N B$ $\mathrm{MB}$

Nathalan, holy man (supp. d. 452): Elva Johnston, xl.264-5; DNB AFP

Odhran, holy man and self-sacrifice (supp. d. c. 563): Marios Costambeys, xli.496

Regulus, supposed founder of the see of St Andrews (supp. $f$. 8th-9th cent.): Ursula Hall, xlvi.373-4; DNB MB

Ségéne mac Fiachna, abbot of Iona (d. 652): see Iona, abbots of

Sléibíne mac Congaile, abbot of Iona (d. 767): see Iona, abbots of

Suibne, abbot of Iona (d. 772): see Iona, abbots of

Suibne moccu Urthrí, abbot of Iona (d. 657): see Iona, abbots of

Ternan, holy man ( $f$ l. 6th-7th cent.): Alan Macquarrie, liv.153-4; DNB AFP

Virgno, abbot of Iona (d. 623): see Iona, abbots of

\section{c. Secular men and women}

Einarr, magnate (fl. early 890s-930s): Barbara E. Crawford, xvii.1023-4

Erlend, earl of Orkney (d. 1098/9): Barbara E. Crawford, xliii.128-9; DNB J. G. Fotheringham

Hákon Paulsson, earl of Orkney (d.c. 1126): Barbara E. Crawford, xxxvi.130-1; DNB A. P. Smyth

Macduff, 'thane' of Fife (fl. 1057-8): Dauvit Broun, xvii.12; DNB T. F. Henderson

Paul, earl of Orkney (d. 1098/9): Barbara E. Crawford, xliii.128-9; DNB J. G. Fotheringham

Robert de Brus, supposed nobleman (supp. d. 1094): Emma Cownie, viii.372; DNB Emma Cownie

Robert Cumin, earl of Northumbria, magnate (d. 1069): William M. Aird, xiv.623; $D N B$ Mandell Creighton

Rögnvald (II) Brúsason, earl of Orkney (d. 1046): Barbara E. Crawford, liv.584-5

Sigurd (II) Hlödvisson, earl of Orkney (d. 1014): Barbara E. Crawford, 1.595- 6

Thorfinn Sigurdson, earl of Orkney (c. 1009-c. 1065): Barbara E. Crawford, liv.584-5 


\section{Anglo-Saxon and related entries in the ODNB (2004)}

\section{LATER MEDIEVAL SUBJECTS (c. 1080-c. 1450)}

Ailred of Rievaulx, religious writer and abbot of Rievaulx (1110-67): David N. Bell, i.491-3; DNB WH

Bower [Bowmaker], Walter, abbot of Inchcolm and historian (1385-1449): D. E. R. Watt, vi.921-2; DNB T. A. Archer

Capgrave, John, prior of Bishop's Lynn, theologian and historian (1393-1464): Peter J. Lucas, ix.991-3; DNB EMT

Dominic of Evesham, Benedictine monk and hagiographer (d. in or before 1150): D. C. Cox, xviii. 802

Eadmer of Canterbury, Benedictine monk and historian (b. c. 1060, d. in or after 1126): J. C. Rubenstein, xvii.530-1; DNB G. G. Perry

Faricius, doctor and abbot of Abingdon (d.1117): Peregrine Horden, xix.43-4; DNBWH Fordun, John, chronicler (d. in or after 1363): D. E. R. Watt, xx.355-7; DNB T. A. Archer

Geffrei Gaimar, Anglo-Norman poet and historian (fl. 1136-7): Ian Short, xx.265-6; $D N B$ C. T. Martin

Gerald of Wales, author and ecclesiastic (c. 1146-1220x3): Robert Bartlett, xx.925-8; $D N B$ H. R. Luard

Geoffrey of Monmouth, bishop of St Asaph and historian (d. 1154/5): J. C. Crick, xxxviii.629-32; $D N B$ H. R. Tedder

Gui, bishop of Amiens (c. 1014-1074/5): Frank Barlow, xxiv.182-3

Hemming, monastic writer (fl. c. 1095): J. F. A. Mason, xxvi.280; DNB CLK

Henry [Henry of Huntingdon], historian and poet (c. 1088-c. 1157): D. E. Greenway, xxvi.413; $D N B$ H. R. Luard

Henry [H.] of Saltrey, Cistercian monk and writer (fl. c. 1184): Yolande de Pontfarcy, xlvii.775-6; DNB CLK

Higden, Ranulf, Benedictine monk and chronicler (d. 1364): John Taylor, xxvii.49-50; DNB CLK

Hugh Candidus, Benedictine monk and chronicler (c. 1095-c. 1160): Edmund King, xxviii.620-1; DNB TFT

Ingulf, abbot of Crowland (c. 1045-1109): Edmund King, xxix.294-5; DNB WH

Jocelin of Furness, Cistercian monk and hagiographer (fl. 1199-1214): Robert Bartlett, xxi.190-1; DNB J. T. Gilbert

John of Tynemouth [Tinmouth], chronicler and hagiographer (fl. c. 1350): John Taylor, lv.795-6; DNB CLK

John of Wallingford, historical writer (d. 1258): Simon Lloyd; Rebecca Reader, xlii.624; $D N B \mathrm{WH}$

John of Worcester, monk and chronicler (fl. 1095-1140): P. McGurk, 1x.292-3; DNB WH

Matthew Paris, historian, Benedictine monk, and polymath (c. 1200-59): Simon Lloyd; Rebecca Reader, xlii.620-8; DNB WH

Orderic Vitalis, Benedictine monk and historian (1075-c. 1142): J. O. Prestwich, xli.921-2; DNB CLK 


\section{Helen Foxhall Forbes et al.}

Osbern, Benedictine monk, hagiographer, and musician (d. 1094?): J. C. Rubenstein, xli.983-4; DNB CLK

Reginald of Coldingham, Benedictine monk and hagiographer (d. c. 1190): V. Tudor, xii.496-7; $D N B \mathrm{MB}$

Robert of Shrewsbury, abbot of Shrewsbury and hagiographer (d. 1168): D. H. Farmer, 1.454; DNB CLK

Roger of Howden [Hoveden], chronicler (d. 1201/2): David Corner, xxviii.463-4; $D N B W H$

Roger of Wendover, historian (d. 1236): David Corner, lviii.106-8; DNB WH

Symeon of Durham, monk and historian (fl. c. 1090-c. 1128): Bernard Meehan, liii.581-2; DNB CLK

Thomas Elmham, historian (b. 1364, d. in or after 1427): S. E. Kelly, xviii.294; DNB T. A. Archer

William Ketel, hagiographer (fl. c. 1100): David Rollason, xxxi.447; DNB CLK

William of Jumièges, Benedictine monk and author (fl. 1026-70): Elisabeth van Houts, xxx.828

William of Malmesbury, historian, man of letters, Benedictine monk (b. c. 1090, d. in or after 1142): R. M. Thomson, xxxvi.348-51; DNB Kate Norgate

William of Poitiers, priest (b. c. 1020, d. after 1087): Marjorie Chibnall, xliv.682-3

William Worcester, topographer and author (1415-80x5): Nicholas Orme, lx.294-5; $D N B$ James Tait

\section{ANTIQUARIES (c. 1450-c. 1750)}

Astle, Thomas, archivist and collector (1735-1803): Nigel Ramsay, ii.771-3; DNB H. R. Tedder

Aubrey, John, antiquary and biographer (1626-97): Adam Fox, ii.907-11; DNB Richard Garnett

Bale, John, bishop of Ossory, evangelical polemicist, and historian (1495-1563): John N. King, iii.482-6; $D N B$ Mandell Creighton

Boece, Hector, historian and college head (c. 1465-1536): Nicola Royan, vi.418-21; $D N B$ AJGM

Bradshaw, Henry, scholar and hagiographer (d. 1513): Joan Greatrex, vii.213; DNB WH

Buchanan, George, poet, historian and administrator (1506-82): D. M. Abbott, viii.468-72; DNB AJGM

Camden, William, historian and herald (1551-1623): Wyman H. Herendeen, ix.603-14; $D N B$ EMT

Coke, Sir Edward, lawyer, legal writer, and politician (1552-1634): Allen D. Boyer, xii.451-63; DNB G. P. Macdonell

Cotton, Sir Robert Bruce, first baronet, antiquary and politician (1571-1631): Stuart Handley, xiii.624-9; DNB Sidney Lee

Davies, John, clergyman and Welsh scholar (c. 1570-1644): Mihail Dafydd Evans, xv.381-2; $D N B$ A. W. Renton 


\section{Anglo-Saxon and related entries in the ODNB (2004)}

Day, John, printer and bookseller (1521/2-84): Andrew Pettegree, xv.584-6; DNB H. R. Tedder

Dee, John, mathematician, astrologer and antiquary (1527-1609): R. Julian Roberts, xv.667-75; DNB Thompson Cooper

Dempster, Thomas, writer (1579-1625): Alexander Du Toit, xv.759-62; DNB Henry Bradley

Dering, Sir Edward, antiquary (1598-1644): S. P. Salt, xv.874-80; DNB S. R. Gardiner

Dodsworth, Roger, antiquary (bap. 1585, d. 1654): Graham Parry, xvi.440-1; DNB Sidney Lee

Dugdale, Sir William, antiquary (1605-86): Graham Parry, xvii.153-7; DNB Francis Espinasse

Elphinstone, William, bishop of Aberdeen and founder of the University of Aberdeen (1431-1514): Leslie J. Macfarlane, xviii.326-8; DNB Alsager Vian

*Elstob, Elizabeth, Anglo-Saxon scholar (1683-1756): Mechthild Gretsch, xviii.335-7; $D N B$ Leslie Stephen

Faussett, Bryan, antiquary (1720-76): Nigel Ramsay, xix.159-60; DNB W. W. Wroth

Gale, Thomas, Dean of York and antiquary (1635/6-1702): Nicholas Doggett, xx.303-5; DNB Gordon Goodwin

Gibson, Edmund, bishop of London (bap. 1669, d. 1748): Stephen Taylor, xxii.68-75; $D N B$ G. G. Perry

Hearne, Thomas, antiquary and diarist (bap. 1678, d. 1735): Theodor Harmsen, xxvi.156-60; DNB H. R. Luard

Hickes, George, bishop and antiquary (1642-1715): Theodor Harmsen, xxvii.5-11; $D N B$ W. D. Macray

Innes, Thomas, Roman Catholic priest and historian (1662-1744): Brian M. Halloran, xxix.307-8; DNB Thompson Cooper

Jones, Thomas, Welsh-language poet and genealogist (1532-1608/9): Daniel Huws, xxx.635-6; DNB DLT

Joscelin, John, Anglo-Saxon scholar and clergyman (1529-1603): G. H. Martin, xxx.714-15; DNB E. T. Bradley

Junius, Franciscus, philologist and writer on art (1591-1677): Sophie van Romburgh, xxx.834-5; $D N B$ W. W. Wroth

Laet, Johannes, merchant and scholar (1581-1649): Rolf H. Bremmer, jun., xxxii.207

Lambarde, William, antiquary and lawyer (1536-1601): J. D. Alsop, xxxii.287-90; DNB Gordon Goodwin

Leland, John, poet and antiquary (c. 1503-52): James P. Carley, xxxiii.297-301; DNB Sidney Lee

Lhuyd, Edward, naturalist and philologist (1659/60?-1709): Brynley F. Roberts, xxxiii.710-12; DNB DLT

Llwyd, Humphrey, antiquary and map maker (1527-68): R. Brinley Jones, xxxiv.174-6; $D N B$ DLT

Lye, Edward, Anglo-Saxon and Gothic scholar (bap. 1694, d. 1767): Margaret Clunies Ross and Amanda J. Collins, xxxiv.849-51; DNB W. W. Wroth 


\section{Helen Foxhall Forbes et al.}

Mac Fhirbhisigh, Dubhaltach Óg, scribe and genealogist (c. 1600-71): Nollaig Ó Muraíle, xxxv.387-8; $D N B$ NM

Morgan, William, bishop of St Asaph and biblical translator (1544/5-1604): R. Geraint Gruffydd, xxxix.152-5; DNB JEL

Nowell, Laurence, antiquary (1530-c. 1570): Retha M. Warnicke, xli.237-39; DNB WH

Ó Cléirigh, Míchél, scribe and chronicler (b. in or after 1590?, d. 1643?): Nollaig Ó Muraíle, xli.433-5; DNB NM

Parker, Matthew, archbishop of Canterbury and patron of scholarship (1504-75):

David J. Crankshaw and Alexandra Gillespie, xlii.707-28; DNB J. B. Mullinger

Prise, Sir John, administrator and scholar (1501/2-55): Huw Pryce, xlv.424-5; DNB W. A. J. Archbold

Prys, Edmwnd, Church of England clergyman and Welsh poet (1542/3-1623):

Gruffydd Aled Williams, xlv.494-5; DNB JEL

Rapin de Thoyras, Paul de, historian (1661-1725): M. G. Sullivan, xlvi.68-71; DNB C. H. Firth

Rawlinson, Richard, topographer (1690-1755): Mary Clapinson, xlvi.162-4; DNB W. D. Macray

Rhys, Siôn Dafydd, grammarian (b. 1533/4, d. in or after 1620): Angharad Price, xlvi.626-7; DNB JEL

Roscarrock, Nicholas, Catholic activist and hagiographer (c. 1548-1633/4): Nicholas Orme, xlvii.730-1; DNB W. A. Shaw

Salesbury, William, translator and humanist scholar (b. before 1520, d. c. 1580): R. Brinley Jones, xlviii.696-9; DNB DLT

Savile, Henry, of Banke, collector of manuscripts (1568-1617): F. J. Levy, xlix.118

Selden, John, historical and linguistic scholar (1584-1654): Paul Christianson, xlix.694705; DNB Edward Fry

Smith, John, historian (bap. 1659, d. 1715): G. H. Martin, li.205-6; DNB Thomas Seccombe

Somner, William, antiquary and Anglo-Saxon scholar (bap. 1598, d. 1669): Peter Sherlock, li.627-9; DNB Thompson Cooper

Speed, John, historian and cartographer (1551/2-1629): Sarah Bendall, li.771-3; DNB AFP

Spelman, Sir Henry, historian and antiquary (1563/4-1641): Stuart Handley, li.791-3; $D N B$ William Carr

Strutt, Joseph, antiquary (1749-1802): Jennifer Harris, liii.120-1; DNB Miller Christy Stukeley, William, antiquary (1687-1765): David Boyd Haycock, liii.231-5; DNB W. W. Wroth

Talbot, Robert, antiquary (1505/6-58): James P. Carley, liii.722-3; DNB AFP

Talbot, Thomas, antiquary (c. 1535-95x9): Ian Mortimer, liii.725; DNB AFP

Thwaites, Edward, Anglo-Saxon scholar (bap. 1671, d. 1711): Margaret Clunies Ross and Amanda J. Collins, liv.732-3; DNB Thomas Seccombe

Turner, Sharon, historian (1768-1847): H. R. Loyn, lv.661-3; DNB Thomas Seccombe

Twysden, Sir Roger, antiquary (1597-1672): David L. Smith, lv.750-4; DNB Thomas Seccombe 


\section{Anglo-Saxon and related entries in the ODNB (2004)}

Ussher, James, archbishop of Armagh (1581-1656): Alan Ford, lvi.6-14; DNB Alexander Gordon

Vaughan, Robert Powell, antiquary (1591/1-1667): Mihail Dafydd Evans, lvi.198-9; $D N B$ JEL

Wanley, Humfrey, Anglo-Saxon scholar (1672-1726): Peter Heyworth, lvii.239-42; $D N B$ W. P. Courtney

Wheelocke, Abraham, Anglo-Saxon scholar (c. 1593-1653): Alistair Hamilton, lviii.444-7; DNB D. S. Margoliouth

Wiliems, Thomas, Welsh lexicographer (b. 1545/6?, d. in or before 1623?): J. E. Caerwyn Williams, lviii.952-3; DNB JEL

\section{MODERN SCHOLARS (c. 1750-)}

*Bateson, Mary, historian and suffragist (1865-1906): Mary Dockray-Miller, iv.331-3; $D N B$ TFT

Bishop, Edmund, liturgical scholar and ecclesiastical historian (1846-1917): R. J. Schoeck, v.864-5

Bond, Sir Edward Augustus, librarian (1815-98): Michael Borrie, vi.509-11

Bosworth, Joseph, Anglo-Saxon scholar (1787/8-1876): rev. John D. Haigh, vi.749-50; $D N B$ Henry Bradley

Bruce-Mitford, Rupert Lee Scott, archaeologist and art historian (1914-94): Martin Biddle, xxxviii.459-60

Chadwick, Hector Munro, literary scholar (1870-1947): rev. John D. Haigh, x.840; $D N B W$. Telfer

*Chadwick, Nora, literary scholar (1891-1972): Paul Knobel, x.847-8

Chalmers, George, antiquary and political writer (bap. 1742, d. 1825): Alexander Du Toit, xi.870-2; DNB AJGM

Cleasby, Richard, philologist (1791-1847): rev. John D. Haigh, xi.999; DNB Richard Garnett

Cockayne, Thomas Oswald, philologist and teacher (bap. 1809, d. 1873): Daniel F. Kenneally, xii.326-7; $D N B$ A. Brodribb

Collingwood, William Gershom, author, artist, and antiquary (1854-1932): James S. Dearden, xii.681-3

Craigie, Sir William Alexander, lexicographer and philologist (1867-1957): A. J. Aitken, xiii.967-9

Dasent, Sir George Webbe, Scandinavian scholar (1817-96): rev. John D. Haigh, xv.217-18; DNB Thomas Seccombe

Earle, John, philologist (1824-1903): rev. John D. Haigh, xvii.570; DNB Charles Plummer

Flower, Robin Ernest William, scholar of Irish literature and poet (1881-1946): Bernard O'Donoghue, xx.177-8; DNB H. I. Bell

Foster, Sir Idris Llewelyn, Welsh and Celtic scholar (1911-84): R. Geraint Gruffydd, xix. 504-5 


\section{Helen Foxhall Forbes et al.}

Freeman, Edward Augustus, historian (1823-92): Frank Barlow, xix.920-4; DNB WH

Galbraith, Vivian Hunter, historian (1889-1976): R. W. Southern, xxi.293-5

Giles, John Allen, translator and literary editor (1808-84): John Blair, xxii.229-30; $D N B W H$

Gollancz, Sir Israel, literary scholar (1863-1930): rev. William Baker, xxii.708-10; DNB A. M. Hyamson

Haddan, Arthur West, ecclesiastical historian (1816-73): rev. Myfanwy Lloyd, xxiv.407-8; $D N B$ WH

Hunt, Richard William, palaeographer (1908-79): David Vaisey, xxvii.866-7

Hunt, William, historian and biographer (1842-1931): Robert W. Dunning, xxviii. $877-8$

Innes, Cosmo Nelson, antiquary (1798-1874): rev. H. C. G. Matthew, xxix.299; DNB W. W. Wroth

Jackson, Kenneth Hurlstone, Celtic scholar (1909-91): William Gillies, xxix.509-10

James, Montague Rhodes, scholar and author (1862-1936): Richard W. Pfaff, xxix.723-6; DNB A. F. Scholfield

Jones, Gwyn, viking scholar (1907-99): Meic Stephens, xxx.504-5

Kemble, John Mitchell, philologist and historian (1807-57): John D. Haigh, xxxi.153-4; DNB WH

Ker, Neil Ripley, palaeographer (1908-82): Teresa Webber, xxxi.388-9

*Law, Vivien Anne, Lady Shackleton, linguistic scholar (1954-2002): Werner Hüllen (online update, October 2006)

Lindsay, Wallace Martin, classical scholar (1858-1937): rev. Roger T. Stearn xxxiii.902-3; DNB C. J. Fordyce

Lowe, Elias Avery, palaeographer (1879-1969): James J. John, xxxiv.563

Magnússon, Eiríkur, librarian and Icelandic scholar (1833-1913): B. S. Benedikz, xxxvi.137-9

Maitland, Frederic William, legal historian (1850-1906): S. F. C. Milsom, xxxvi.204-10; $D N B$ B. F. Lock

Morris, William, designer, author and visionary socialist (1834-96): Fiona MacCarthy, xxxix.317-24; DNB J. W. Mackail

Napier, Arthur Sampson, philologist (1853-1916): M. K. C. MacMahon (online update, October 2007)

O'Curry, Eugene, Irish scholar (1794-1862): Fergus Kelly, xli.483-4; DNB NM

O’Donovan, John, Gaelic Irish scholar (1806-61): Nollaig Ó Muraíle, xli.527-9; DNB NM

Pinkerton, John [pseuds. Robert Heron, H. Bennet], historian and poet (1758-1826): Sarah Couper, xliv.373-5; DNB T. F. Henderson

Plummer, Charles, historian (1851-1927): R. J. Schoeck, xliv.612-13

Rhŷs, Sir John, Celtic scholar (1840-1915): rev. Mari A. Williams, xlvi.623-4; DNB John Fraser

Robertson, Eben William, historian (1815-74), rev. Nilanjana Banerji, xlvii.223; DNB Thomas Seccombe 


\section{Anglo-Saxon and related entries in the ODNB (2004)}

Robinson, Joseph Armitage, dean of Westminster and Wells (1858-1933): T. F. Taylor, xlvii.376-8; $D N B$ Claude Jenkins

Scott, Sir Walter, poet and novelist (1771-1832): David Hewitt, xlix.490-510; DNB Leslie Stephen

Simpson, William Douglas, archaeologist and historian (1896-1968): A. T. Hall, 1.718-9

Skeat, Walter William, philologist (1835-1912): rev. Charlotte Brewer, 1.817-19; DNB Kenneth Sisam

Skene, William Forbes, historian and Celtic scholar (1809-92): rev. W. D. H. Sellar, 1.854-6; DNB AJGM

Smith, Charles Roach, antiquary (1806-90): Michael Rhodes, li.67-9; DNB W. P. Courtney

Stenton, Sir Frank Merry, historian (1880-1967): J. C. Holt, lii.405-7

Stephens, George, philologist and runologist (1813-95): Andrew Wawn, lii.466-8; $D N B$ Henry Bradley

Stevenson, Joseph, historian and archivist (1806-95): Francis Edwards, lii.588-90; $D N B$ Thompson Cooper

Stevenson, William Henry, historian and philologist (1858-1924): rev. G. H. Martin, lii.612-13; DNB A. L. Poole

Stokes, Margaret M’Nair, archaeologist (1832-1900): rev. Marie-Louise Legg, lii.871-2; $D N B$ C. L. Falkiner

Stokes, Whitley, Celtic scholar (1830-1909): Nollaig Ó Muraíle, lii.872-4; DNB NM

Strachan, John, classical and Celtic scholar (1862-1907): rev. Mark Pottle, lii.992-3; $D N B$ Peter Giles

Stubbs, William, historian (1825-1901): James Campbell, liii.217-22; DNB TFT

Sweet, Henry, phonetician and comparative philologist (1845-1912): M. K. C. MacMahon, liii.447-50; DNB T. C. Onions

Taylor, Harold McCarter, architectural historian (1907-95): Greg Waite, liii.896-7

Thompson, Sir Edward Maunde, palaeographer (1840-1929): Michael Borrie, liv.420-1; DNB F. G. Kenyon

Thorpe, Benjamin, Anglo-Saxon scholar (1781/2-1879): rev. John D. Haigh, liv.664-5; $D N B$ Thomas Seecombe

Todd, James Henthorn, biblical scholar (1805-69): rev. Sinéad Agnew, liv.883-4; DNB E. M. Todd

Tolkien, J. R. R., writer and philologist (1892-1973): T. A. Shippey, liv.902-5; DNB Humphrey Carpenter

Turville-Petre, (Edward Oswald) Gabriel, Icelandic scholar (1908-78): Heather O’Donoghue, xliii.907-8

Vigfússon, Guðbrandur, scholar of Icelandic literature (1827-89): rev. Carolyne Larrington, lvi.468-9; DNB F. Y. Powell

Wallace-Hadrill, (John) Michael, historian (1916-85): Karl Leyser, xxiv.438-9

Westwood, John Obadiah, palaeographer (1805-93): Yolanda Foote, lviii.318-19; $D N B$ B. B. Woodward 


\section{Helen Foxhall Forbes et al.}

*Whitelock, Dorothy, historian (1901-82): Simon Keynes, lviii.692-4

Wormald, (Charles) Patrick, historian (1947-2004): Alex May (online update, January 2008)

Wormald, Francis, palaeographer (1904-72): Michael Borrie, 1x.331-2

Wright, Joseph, philologist and dialectologist (1855-1930): Arnold Kellett, lx.464-7; $D N B$ J. Boyd 